\title{
THE ORIGINS AND NATURE OF TURKISH POWER
}

\author{
Carl Max KORTEPETER \\ (New York)
}

I

In this year 1971, it is most fitting that the scholarly world give recognition to the 900th anniversary of an event which changed decisively the course of world history. I am speaking of the victory of the Seljuk Turks over the Byzantine Empire near the town of Manzikert in the year 1071, a victory which opened up Asia Minor to Turkish conquest and settlement, sounded the death knell of the East Roman Empire and laid the foundations for the subsequent expansion of the Ottoman Empire into Europe, Asia and Africa. Two centuries after Manzikert, the Osmanli (Ottoman) Turks began drawing upon the, by then firmly entrenched ethnic and cultural reservoir of Turkish Asia Minor to propel itself into the position of a world power in Europe and the Eastern Mediterranean, a position which it held from the fifteenth up to the nineteenth centuries. While students in North America and Western Europe have traditionally received an exaggerated picture of the grandeur of the Spanish, the Austrian, the British, the French or the Russian Empires, seldom until recently have either teachers or students asked themselves, "Who were the Ottoman Turks, those great protagonists of Europe, about whom so many of the leading literary and religious figures of Western Europe, not to mention the diplomats and politicians, were preoccupied from the fifteenth to the nineteeenth centuries?"

In truth, the Western World, until our own times, has been content to live in smug ignorance of Asia in general and of the Ottoman colossus in particular in spite of the fact that the Turks historically controlled the land bridge from Iran to China and in modern times controlled Hungary for 150 years, most of the Balkan peninsula until the late nineteenth century and maintained its sovereignty over most of the Arab World until World War I.

During the course of modern history since $1500 \mathrm{~A}$. D., it is clear that the ruling elites of Europe were content to describe the Ottoman Turks to their subjects in the most derogatory terms, for the Ottomans posed not simply a 
political threat to these elites, but also social, (i. e., religious) and economic threats to much of southern and eastern Europe. ${ }^{1}$ While the rulers of Europe, whether kings, clergy, academicians or merchants, wished to keep the common people ignorant of the true nature of the Islamic-Ottoman civilization, they personally sought information from every quarter about the origins, the strengths and the weaknesses of the Turkish state. ${ }^{2}$

Today a historian concerned with the nine hundred year span of Turkish prominence in the eastern Mediterranean, must continually sift through essentially two types of historical literature: on the one hand, those tracts and propogandistic materials which distort or castigate the Turkish imperial system or the Islamic, faith and on the other, serious essays, reports and official documents which reveal the inner workings of an empire spanning history from the thirteenth to the twentieth centuries. ${ }^{3}$

In view of the bias against the study of the Middle East in anything but a Biblical context until recently, we have only begun to unlock the secrets of those centuries when the political and financial support of the Ottoman Sultan determined the success or failure of the Protestant Reformation, the longevity on the throne of French and English rulers, the survival of Muscovy or the Polish- Lithuanian Commonwealth, or the rescue of the Sephardic Jews from Spanish persecution and murder. ${ }^{4}$ One should also not be surprised to learn

1 The "Fear of the Turks" permeates the literature of the sixteenth and seventeenth century Europe. There is an excellent bibliography of such material in S. Fischer-Galati, Ottoman Imperialism and German Protestantism (Cambridge, Mass., 1959), in the standard German Bibliographies under Türkenfurcht and in the study by Myron Gilmore, The World of Humanism (New York, 1952), pp. 273 ff.,

2 For insight into the type of serious literature available to the elite of Europe, see C. M. Kortepeter, "German Zeitung Literature", in R. Schoeck, ed., Editing Sixteenth Century Texts (Toronto, 1966), pp. 113-129. Recently also, some translations have been made of the Venetian Relatione. See J. C. Davis, Pursuit of Power (New York, 1970), Harper Torchbooks, TB 1533.

3 See, in addition to the above, Norman Daniel, Islam and the West-the Making of an Image (Edinburgh, 1960) and C. Göllner, Turcica: Die europäischen Türkendrucke des xvi. Jahrhunderts (Bucharest, 1961).

4 Here one needs only to consider some of the standard incidents of West European history in the light of Turkish realities. Thus, it was English bravery which helped to sink the Spanish armada in 1588 but Phillip II of Spain might have turned once again to English conquest had not his Habsburg cousing in Austria become involved in a long war with their mutual enemy, Ottoman Turkey. It is also common knowledge that good relations between Francis I of France and Suleiman the Magnificent helped check France's encircling enemies. Sephardic Jewry after its expulsion from Spain found its chief refuge in Ottoman Turkey. 
that the Turks themselves have left many pages of their history either unexplored or only dimly illuminated. Seldom do men of action or affluence have the time, the inclination or the perspective to record details of their exploits for the pleasure and admiration of succeeding generations. Thus, the Ottomans even maintained myths about their origins, which were created by the myth-makers of the expanding and self-conscious empire already in the fifteenth century. Hence, Turkish historians of today must often subject to analysis and updating myths which have been a part of Turkish historiography and folklore for up to five centuries.

\section{II}

In a commemorative volume dedicated to 900 years of Turkish preeminence in World History, one may perhaps be forgiven for taking another look at the pre-Ottoman and the formative years of the Ottoman Empire in an attempt to clarify for one's self and for one's students and colleagues the essential features of a complex political and social phenomenon which might be termed, "The Origins and Nature of Turkish Power in Western Asia." The task is somewhat more difficult than one might imagine chiefly because scholarship today has become so compartmentalized and specialized that the research findings of Sinologists, Turcologists, Islamic Historians, economists, sociologists and political scientists, some of whom, for example, may be working on the ethnology of the Turks, may not become known to colleagues in neighboring fields for many years. Recently this writer made his first incursion into the treacherous territory of early Ottoman history with an essay entitled, "The Islamic-Ottoman Social Structure: the Quest for a Model of Ottoman History." The purpose of that essay was to call attention to three basic sources of the Islamic-Ottoman social order: the Platonic political-philosophic tradition as it was incorporated into the writings of the Islamic political philosophers; actual Islamic political practices, and in particular, the survival and renewal of Irano-Islamic political institutions among the Samanid, Ghaznavid and Seljuk states; and finally, the pragmatic and creative abilities of the Ottoman-Turkish leadership as they blended new and old institutions to lay the foundations of a new empire. While scholars have recently directed their attention to the above-mentioned theoretical (i. e. Hellenistic) and traditional (Arab-Iranian Islamic) elements in the Ottoman heritage, the prag-

5 To be found in R. B. Winder, ed., Near Eastern Round Table I (Turkish History and Politics) (New York, 1969), pp. 1-40. 
matic and the Turkish ethnological elements have largely remained unreported in Western Languages. In Turkey, by contrast, though such efforts were on occasion a bit overzealous, scholars, politicians and publicists, Ziya Gökalp, Fuat Köprülü, and Kemal Atatürk to mention only the most well-known, sought to bring new information to the field of schelarship about the purely Turkic elements of the Islamic and pre-Islamic past in order to place Turkish nationalism, the ideology of the Republic of Turkey, on a firm footing. Here, it is my own curiosity about the qualities and abilities of the pre-Ottoman Turks-an aspect of the Turkish past which is poorly studied and even less understood-which has led to the writing of this article, and I attempt this survey with one basic assumption: that the Turks possessed more-than ordinary skills or else they could not have founded one of the longest surviving empires in history.

\section{III}

I begin this analysis by stating that for a twentieth century Islamic historian, one of the central questions of Islamic history surely must be: How were the Turks able to conquer and control vast and important territories in the central Islamic lands from the eleventh to the twentieth centuries? Or, to put the question somewhat differently: Why were the Turks, generally speaking, more single-minded and efficient politically than were the other peoples of the Middle East and south eastern Europe?

It is clear that the qualities of leadership so evident among the Turks of the fourteenth century did not accrue in any short period of time. It is thus proposed here to probe briefly the pre-Ottoman qualities and accretions of Turks according to the following rough geographic and chronological sequence:

A. Economic Necessity and the Evolution of Turkish Power on the Chinese Frontier.

B. Why did the Nomads Invade the Agriculturally-based Empires?

C. Who Were the Oghuz and What Pressures Drove Them Westward?

D. How Was Economic and Political Power Reinforced Culturally?

E. The Seljuk Conversion to Islam and Some Questions of Turkish Power in Western Asia.

6 This discussion is a continuation of remarks $I$ have made in a review of Professor Claude Cahen's book (Pre-Ottoman Turkey (New York, 1968) in the Middle East Journal $25 / 2$ (Spring, 1971), pp. 262-267. 
F. The Dynamics of Early Ottoman State Formation.

\section{A. Economic Necessity and the Evolution of Turkish Power on the Chinese Frontier}

The Islamic historian, Claude Cahen, ${ }^{7}$ has made a preliminary probe into the origins of Turkish adaptability and organizational skills and has given much credit to the wide-ranging nature of Turkish steppe nomadism. The implication here appears to be that to move peoples over great distances requires a great deal of organization and efficiency. While not denying this valuable clue which Owen Lattimore has greatly elaborated, ${ }^{8}$ I should like here to examine a number of essential features of the 'Turkish system' from the Chinese and Central Asian past of the Turks in order to determine whether such characteristically Turkic features might give to us some new insights about the formative years of the Ottoman State. It is obviously no longer adequate or helpful to state, as so many authors have in the past, that 'the Turkish migrations into the Middle East between the ninth and the thirteenth centuries are the result of obscure political movements on the borders of China.'

Historians today are fully aware that the historiography of a given era tends to reflect the peculiar insights, tastes and needs of that era. I have already mentioned that Fuat Köprülü and Ziya Gökalp among others conducted research into the pre-Islamic past of the Turks. Such an emphasis prompted Köprülü, as a part of his research on early Turkish literature ${ }^{9}$ to report on the "Influence du Chamanisme Turco-Mongol sur les ordres mystiques musulmans." ${ }^{10}$ As a rather amusing aside, Köprülü noted that all shamans sported handle-bar mastaches. More recently, Abdülkadir Inan has called attention to vestiges of shamanism still visible among many Anatolian Turks to this day. ${ }^{11}$ Clearly the study of the pre-Ottoman history of the Turks has produced important information which bas been poorly reported in Western scholarly literature. Doubtless Islamic art historians have done more than any other branch of Islamic scholarship to indicate the important influence of Central Asian and Chinese art forms on craftsmen of the Middle East.

7 See Cahen, Pre-Ottoman Turkey, especially pp. 32-34.

8 0. Lattimore, Inner Asian Frontiers of China (American Geohraphic Society Research Series, 21) (New York, 1940), pp. 67-73 and passim.

9 Türk Edebiyatında Ilk Mütessavıflar (Istanbul, 1919).

10 In Memoirs de l'Institut de Turcologie de l'Université de Stamboul, N. S. I (1929), pp. 5-19.

11 Tarihte ve Bugün Şamanizm (Türk Tarih Kurumu Yay. VII/24 Ankara, 1954). 
It is quite clear also that even as the Turks and the Mongols brought an eastern caste of mind and rich cultural gifts to the Middle East, and ultimately to Europe, from the Chinese cultural sphere, the converse is also true. During the era of Mongol rule in China [the so-called Yüan Dynasty (12601368)] and under the succeeding Ming Dynasty (1368-1644), the Islamic faith and institutions became very influential in Eastern Asia. ${ }^{12}$ George Vernadsky, in his study, The Mongols and Russia, and other critical work of the era, have estableshed clear connections between Russian institutions and institutions established during the long Mongol-Turkic rule of the Golden Horde in Russia (ca. 1240-1480). ${ }^{13}$ But if we are to understand the qualities of Turks which prepared them for the political leadership of the Middle East for nine centuries, we must probe further back than the era of Jenghiz Khan (d. 1227) into the Central Asian and Chinese past of their Seljuk and Oghuz forbears. Such a probe may not of course be accomplished without recourse to the spadework of a number of distinguished Sinologists and Turkologists.

On the basis of the very important studies of such scholars as Lattimore, Eberhard, Köymen, Sümer, Wittfogel, Fêng and Hamilton, Islamic historians are in a much better position today than previously to understand the rhythm of invasions from the Eurasian steppe into the Middle East and Eastern Europe in general and the nature of Turkish power in particular. Eberhard in his article, "Die altchinesische Kultur und die Türken," the formation of the first distinctive Chinese culture (Shang-Kultur) between the years 1500 and 1050 B. C., Köymen, in his article, "Der Hsiung-Nu-Stamm der Tu-ku (T'u-ko)," has made a strong case for Tu-ku, i. e., Turkish family and tribal leadership of the Hsiung-Nu federation and has further associated the name, T'u-chüeh (T'yu-Kyu) with a later Chinese transliteration of the most prominent Turkish noble tribe of Tu-ku. ${ }^{15}$ To gain the fullest

12 See the recent and important edition and translation of the Muslim merchant, Ali Ekber's account of his trip to China which was presented in 1516 to Sultan Selim I: Lin Yih-Min, Ali Ekber'in Hitayname adli Eseri (Tai-Pei, 1967), pp. 4-5.

13 See for example, B. Spuler, Die Goldene Gorde. Die Mongolen in Russland 1223-1502 (Leipzig, 1943), G. Vernadsky, The Mongols and Russia (New Haven, 1953), and Michel Roublev, "Le Tribut aux Mongols d'après les Testaments et Accords des Princes Russes," Cahiers du monde russe et soviétique, VII (1966), pp. 487-530.

14 In Ankara Üniversitesi Dil ve Tarih-Coğrafya Fakültesi Dergisi I/4 (May-June, 1943), pp. $31-38$.

15 In the Ankara Üniv. D. ve T.-C. Falk. Dergisi III/1 (Nov.-Dec., 1944), pp. 51-68 and the accompanying geneological table. 
benefit from the ideas of Eberhard, Lattimore and Wittfogel, one must have an elemental knowledge of Chinese and Central Asian geography to wit: the Huang Ho (Yellow) and the Ch'ang Chiang (Yangtze) river basins as the centers of primary Chinese agricultural civilization; the location of the steppe and the Gobi desert ot the north, with Outer Mongolia beyond the desert and Manchuria to the northeast of the Yellow River beyond the Great Wall; the location of the string of oases reaching into Eastern Turkestan, accessible from China by way of the steppe and desert and which are bordered onfshe north by the Altainand T'ien Shan mountains, on the west by the Pamirs, and the south by the Kun-Lun range. Also one must be aware that nomads had ready access to the western (Eurasian) steppe from Jungaria, between the T'ien-Shan and Altai mountains or from Outer Mongolia. In fact, for the history of Central Asia, the historical atlas of China by Albert Herrmann as revised by Norton Ginsburg is an indispensable tool. ${ }^{16}$

In the view of Eberhard, the Turko-Mongol steppe peoples, who had distinguished themselves from their more agriculturally oriented neighbors by the eleventh century B. C., imposed their rule over northern China about 1050 B. C.. In the relatively short period of time, during which the northwestern Turko-Mongol (Chou) peoples and the eastern agriculturists, the Tai people intermingled, social and economic characteristics, such as the centrality of the family and the emergence of a feudal gentry, emerged in the resultant Shang society which have been the hallmarks of Chinese civilization ever since. It is to this extent then that the Turko-Mongol peoples can be said to have influenced and served as a catalist for the formation of the primary Chinese society. It is doubtless for this reason also that the careful observer will be struck by many similarities between the Chinese and Turkish family structures. ${ }^{17}$ Eberhard concludes his early discussion of Turco-Mongol contacts with China by denoting the main lines of Turkish culture of that era: the Turks were primarily breeders of horses but also maintained seasonal plots of grain and other agricultural produce; they worshipped a heavenly god who was represented by the sun; the stars and their movement played a role in

16 An Historical Atlas of China (Chicago, 1966). The prefatory essay of the Atlas, prepared by Paul Wheatley, serves to elucidate certain errors or controversial issues in the plates. One must indeed regret that the plates were prepared without reference to James Hamilton's excellent article which had appeared already in Journal Asiatique in 1962, some four years prior to the publication of the revised edition of the Atlas.

17 For a brief but adequate elaboration of the Chinese family system, see K. S. Latourette, The Chinese, Their History and Culture II (New Tork, 1934), pp. 183-196. 
their cult as did fire; the Turks possessed a highly developed political system and society was closely stratified. In fact, in Eberhard's opinion, it was particularly in the realm of political organizational ability that the early TurkoMongol ruling elite of the Chang period influenced the future course of Chinese development. ${ }^{18}$

Eberhard clarifies in somewhat greater detail his ideas of the impact of nomadic society on agricultural society in his study, Conquerors and Rulers, Social Forces in Medieval China (Leiden, 1952). In his opinion, Chinese feudalism developed as a result of nomad incursions. He contends that in China, and elsewhere, feudalism, defined as the assigning of certain rights to an individual over a piece of land in exchange for specific obligations, could only flourish where communications were poor and where the basic production was agrarian, with the prevalence of a natural (barter) economy. But, he emphasizes, feudalism is not produced by such conditions per se, but it results from a nomadic conquest of an essentially agrarian society. ${ }^{19}$

Lattmore approaches the early frontier history of China in somewhat different fashion. He asks the initial question: When did mutually hostile forms of society emerge $?^{20}$ In his opinion, this crucial stage in the development of man in the Chinese cultural sphere came about when the distinction emerged between stall-fed horses which pulled chariots and carts and pasturefed horses which were used for travel and food. As pasture-fed horses, because of energy expended in grazing, performed less work, there was a need for many horses and an extensive economic organization to move these horses from pasture to pasture. Lattimore notes also that irrigated agriculture did not become the determinent of differentiation between nomad and farmer until the fourth century B. C.. This observation appears to take issue with the ideas of Wittfogel concerning the central role of irrigation in 'Asian autocratic systems."

18 Eberhard, Ankara Univ. D. ve T.-C. Fak, Dergisi I/4, pp. 36-38; Herrmann, p. 4; and Lattimore's mild criticism of Eberhard's position in his Studies in Frontier History, Collected Papers, 1928-1958 (London, 1962), pp. 530-531 and Köymen, D. ve T.-C. Fak. Dergisi III/1, pp. $60-61$.

19 It is to be remembered that the nature of Chinese social organization and the question of whether or not it may be termed 'feudalism' is one of the most controversial issues among Sinologists. See here, Eberhard, Conquerors and Rulers, pp. 24-34. This Eberhard thesis resembles that of Lattimore as set forth in Studies in Frontier History, p. 89, where Lattimore observes that 'Chinese' who adopted the steppe economy became 'tribal barbarians' while nomads who penetrated into China became members of the Chinese ruling class.

20 Lattimore, Inner Asian Frontiers, p. 58. 
In an essay on the 'sedentary origins of nomadism,' Lattimore probes even deeper into the origins of the Turks. He contends, rightly it seems, that a steppe oasis favors the domestication of animals and, in fact, without domesticated animals, the steppe is unsafe for humans. Moreover, he reasons, knowledge of castration was essential to the techniques of pastoralism because without this knowledge it would be inconceivable to control large herds of horses in which the stallions would always be contending for their own herds. In short, Lattimore sees pastoral nomadism as secondary to agriculture and deriving from it. With growing scarcity of land, the agriculturalist is forced to cultivate progressively more marginal land in the direction of the steppe and away from adequate rainfall, irrigation systems, or cheap river transportation. Eventually the marginal farmer finds his flocks or horses a more reliable source of subsistence than his plot of ground, and consequently, he becomes almost completely dependent on grazing and the high mobility which this economy requires. The pastoralist, of necessity, becomes highly skilled in the control of horses. Later, his military prowess was greatly improved by the acquisition of the compound reflex bow and the stirrup, both of which added accurate fire power to the mobility of the horse. ${ }^{21}$

Descending from the realm of these provocative theories, it is refreshing to learn from written Chinese sources of actual strategems which these two contending ways of life practiced towards each other. An imperial advisor flourishing in the Han period (206 B. C.-220 A. D.) by the name of Chia I (fl. 200-168 B. C.), indicated in a treatise on the Hsiung- Nu that it should be the aim of Chinese policy to make the Hsiung-Nu upperclass dependent upon Chinese imports. ${ }^{22}$ By contrast, a Chinese eunuch serving in the imperial palace (fl. 179-157 B. C.) fled to the Hsiung-Nu court because he harbored grudge against the then reigning Chinese emperor. The eunuch rebuked the Hsiung-Nu (nomadic) ruler for coveting the silks of China and its foodstuffs for, he said, this would have a debilitating effect on the independent power of the nomads. Lattimore cites this story to illustrate his point of view that it was thus not the 'push' of expanding silk production but the 'pull' of transfrontier caravan merchants and middlemen which accounts for the trade in

21 Ibid. pp. 64-65, 158-162.

22 Eberhard, Conquerors and Rulers, p. 75.

23 Lattimore, Inner Asian Frontiers, pp. 487-495; the economic argument here is echoed in H. G. Creel's article, "The Role of the Horse in Chinese History", American Historical Review LXX/3, pp. 647-672. Cf. also Burton Watson, tr., Records of the Grand Historian of China (SsuMa Ch'ien) II N. Y., 1961), p. 170. 
silk to the West. The Chinese thus first became interested in occupying the western oases, such as those found in Eastern Turkestan (Sinkiang), not primarily to sell silk and other products, but to keep the wealth of the oases out of nomad hands and also to eliminate the possibility of invasion from that quarter. ${ }^{23}$ Finally, it is interesting to note that early Han policy concentrated on the objective of preventing the defection of leaders in the pay of Chine along the marginal lands of the steppe border. The primary mission of these Chinese 'Wardens of the Marches' was to hold frontier populations within the Chinese orbit. Nomadic chieftains with designs on China naturally attempted to win over the marches either by persuasion of sudden attacks. ${ }^{24}$

Apart from the above-noted facts and theories about the origins and way of life of the steppe-dwelling 'horse nomad', both Eberhard and Lattimore give considerable attention to the mechanisms which propel the steppe dwellers into the settled lands. Obliquely also, both Eberhard and Lattimore make critical remarks about the role of 'hydraulic society' and its relation to 'oriental despotism', a theory discussed in some detail in Karl Wittfogel's book, Oriental Despotism (New Haven, 1957). The basic criticism of Wittfogel's thesis appears to be that the complex phenomena of any society cannot be reduced to one or two economic considerations such as the task of administering an irrigation system. ${ }^{25}$

Eberhard, in delineating his cyclical theory, first of all makes the broad statement: "We should always keep in mind that differences of race, nationality and language played no role in these nomadic empires." Basic to Eberhard's theory is the deliniation of three main types of nomadic social structure:

a. The Tibetan-Here the basic economy is sheep breeding, basically at high altitudes. Consequently, the Tibetans are broken up into small units and will only fight when seriously provoked and then usually as foot soldiers.

b. The Mongolian- The Mongols are basically cattle raisers, depending on the clan, which means they are mobile but slow. Their social organization is much stronger than the Tibetan as the tribes have traditional chiefs, but in contrast to the Turks, there is an essential

24 Lattimore, Inner Asian Frontiers, pp. 477-480; and Watson, Grand Historian II, pp. 155-193, passim.

25 See, for example, Eberhard's criticism in Conquerors and Rulers, pp. 19-25 and Lattimore's comments in Inner Asian Frontiers, pp. 530-551. 
equality of tribes. A chief of a federation is basically obeyed for a lifetime only.

c. The Turkish- The Turks were basically horse breeders. This factor is reflected in their social structure which is distinguished by the basic inequality of tribes. There was often a traditional 'leader tribe' which supplied leaders for tribal confederations, viz. the Tu-Ku and and the Uighur. There were also ordinary tribes and slave tribes.

Thus, the bases of Turkish political economy developed out of the necessities of a pastoral economy and horse nomadism, which required much more organization than did the grazing of chiefly sheep or cattle. The tasks devolving upon the Turkish leaders were also quite exacting. Some of these tasks included:

i- assigning and protecting summer and winter pastures;

ii- coordinating the movement of the tribe from pasture to pasture in the interests of safety from attack;

iii- as the tribe or tribes often covered great distances, skills in planning, diplomacy and military leadership were essential;

iv- support of the family hierarchical system because the property of each family was of high value and a measure of family status; moreover, as the breeding of horses is a special skill and their reproduction relatively slow, family activities must also be carefully planned and controlled;

v- Seasonal agriculture at a given grazing ground was probably in the hands of the women. ${ }^{26}$

To grasp how intimately Turkish nomadism and even Turkish politics of a bygone era were connected with the horse, one would do well to consult the article, "The Cult of the Horse in the Turkish Onomastique," by A. Caferoğlu. Often the color or the breed of a horse was connected with one particular tribe or with the order of battle of an army. It is interesting to note also that the Turkish word $i l$ which translates roughly as 'realm, province' was explained thus by the great Turkish lexicographer of the eleventh century,

26 Eberhard, Conquerors and Rulers, pp. 68-73; also, on the problems of horse breeding. which Creel contends the Chinese never fully mastered, Cf. Creel, loc. cit.; note Lattimore's criticism of Eberhard's threefold classification of nomads in Studies in Frontier History, pp. 532538. 
Mahmud al-Kashgari: "The word $i l$ is a term which applies to the horse; horses are the wings of the Turks. The trainer (or groom) who cares for the horses is called il başi which means (by extension) the head of a province. The reason for this usage is that whoever trains the horses is indispensable (to the tribe)." 27 As we have here touched upon the lexicographic evidence for the importance of earlier institutions, it is also interesting to note that the word for 'horse or camel trainer (säyis)' in Arabic derives from the same root as does siyāsa, the Arabic word for 'management, rule, government, politics,' thus originally the 'managing of horses or camels.",28

\section{B. Why Did the Nomads Invade the Agriculturally-Based Empires?}

Having discussed the importance of the horse, his training and the premium placed on mobility among 'horse nomads' in order to graze the herds, we are now in a position to elaborate Eberhard's cyclical theory of conquest and the acculturation or re-conquest taking place between the nomads and the agriculturalists in the Chinese cultural sphere. To initiate his cycle, Eberhard envisages the nomad clans as living in loose connection with each other on the steppe near the deliniated borders of China. Through a system of market exchange, pastoral products are amicably traded for agricultural and handerafted goods. But as the rate of exchange shifts against the nomad (and the mechanism of this key shift is not explained), ${ }^{29}$ the nomad gradually begins to seize by raiding what he cannot obtain by market exchange. Now the agriculturist neighbors of the nomads take defensive precautions against the nomads and the clans, in turn, (perhaps feeling the lack of certain essential items of exchange-weapons or food-or commercial items) unite under a capable and daring leader. If the nomad armies are successful, they abandon their marginal agriculture altogether and take their foodstuffs from the farmers at will. Now open warfare develops between the Chinese state defending the farmers and the nomadic confederation. Eventually the federation either wins over the agricultural-based empire or is defeated by it. In either case,

27 A. Caferoğlu, "Türk Onomastiğinde 'At' Kültü," Türkiyat Mecmuası X (1953), pp. 202 and 205 citing Mahmud Kaşgari, Divan-i Lugat it-Türk (edited and translated by Besim Atalay) I, pp. $48-49$.

28 See, for example, E. W. Lane, An Arabic-English Lexicon, Book I, Part 4 (London, 1872), pp. 1465-1466. In Chinese, the word denoting the 'control of a horse drawn vehicle' $Y U^{\prime}$ (ILFP) is also the metaphor for 'controlling the state.' I am grateful to my Sinologist colleague, Moss Roberts, for making this observation. which ties in with Lattimore's theory noted above.

29 Eberhard, Conquerors and Rulers, pp. 75-85. 
Eberhard feels that the nomad empire is doomed to ultimate failure because of either the struggle for power among competing tribal leaders if victorious or the struggle for subsistence if thrown back into the steppe upon defeat. Thence the cycle begins again.

In the opinion of this writer, the Eberhard theory has one major flaw. The blame always appears to be placed on the nomad for disturbing the peace. Actually, however, the original market imbalance is the starting point and could be 'caused' by either type of producer and might well originate from an increase in population or immigration on either the steppe or the farms. The nomads, with more mouths to feed, would tend to encroach on marginal farmland for additional pasturage' conversely ,the farmers, faced with an increase in population, would plow up more of the steppe fringes than previously or 'charge' more for their produce, thus impinging on nomad pastures or increasing 'costs' for the nomads. Hence we have here an ancient version of the feuds between the cattlemen and the farmers in the American West. ${ }^{30}$

Eberhard, after delineating his cyclical theory, turns to the successful nomad empires of medieval China to demonstrate the degree of experimentation they undertook to maintain their pastoral life and at the same time exert their control over the traditional Chinese agricultural state. The Hsiung-Nu (fl. 200 B. C.-100 A. D.) ${ }^{31}$ found it relatively easy to replace the individual tribal chiefs by members of their own family. It was more difficult, however, to convert the tribal organization to a centralized military structure in order to maintain a permanent rule over a large agricultural area. Clearly the Turkish stratified tribal structure, as outlined above, lent itself best to the absorption of various types of military structures including infantry. The T'o-pa or Tabgacb, later Wei (fl. 398-560 A. D.), attempted to identify tribal leaders with the Chinese gentry and the tribesmen with the farmers, but the traditional enmity between the farmer and both the gentry and the nomads, together with the weakening of the tribal leader's authority because of his growing

30 In the Records of the Grand Historian of China (Ssu-Ma Ch'ien), we read that in times of peace, "...Emperor Ching once more renewed the peace alliance with the Hsiung-nu, allowing them to buy goods in the markets along the Han border and sending them supplies and a princess of the imperial family...." (p. 176) This passage clearly shows that the Hsiung-nu had the upper hand, while at a later date when the Han became dominant, ..." the Han continued to expand its agricultural lands in the north until the frontier had been pushed out as far as Hsüanlei." (pp. 185-186).

31 For orientation on a map, see Harrmann, plates 10-12. 
attachment to the city, understandably upset this arrangement. ${ }^{32}$ This system of placing tribal leaders on the roles of the gentry brings to mind the Byzantine and Muscovite Russian practices vis-â-vis invading pastoral peoples.

The Sha-y'o ( Sart), who were closely associated with the 'Five Dynasties' (907-960 A. D.) exhibited as a ruling class the typical characteristics of the nomadic Turks. They worshipped the heavenly god (T'ien-Shen), sacrificed horses on sacred mountains, distributed the Chinese state trasury to their followers as if it were booty, and practiced a system of adoption of neighboring tribes into their ranks. They issued the so-called'iron bulls' ( $\sim$ Mongol paizah), the bearer of which could neither be punished, deposed nor taxed. Eberhard, probably correctly, relates this bull or decree to the ancient Turkish practice of issuing a tarhanlik $(>$ tarhan $=$ blacksmith, perhaps deriving from the nomadic respect for the ancient forger of weapons). We learn also that the Sha-t'o used singing (i. e., hollowed out) arrows as military signals, sent messages in 'wax letters,' probably a kind of yarlik sealed with wax, posted victory flags (lou-pu), loved to participate in earlier forms of football, polo, wrestling and played martial music. ${ }^{3.3}$

Referring obliquely to the T'yu Kyu (confederation (fl. 500-840 A. D.), who maintained control of the inner Asian trade routes for several centuries, Eberhard, drawing particularly upon the work of Annemarie von Gabain, notes the tendency of tribal leaders to become ever more interested in investment and the accumulation of wealth by controling the inner Asian oases and the east-west trade routes. In particular, it was the Uighurs and their Sogdian relatives who excelled in oasis and caravan management. ${ }^{34}$

Owen Lattimore, in an essay on 'The Geographic Factor in Mongol History, ${ }^{35}$ first presented in 1936, dealt with the problem of how nomadic incursions are generated by refuting Toynbee's theories of nomads being "pushed off" the steppe by climatic change (aridity) or "pulled off" the steppe by the breakdown of sedentary civilizations. The author's main point was that such a view was understandable for someone who viewed nomads as living a simple

32 Herrmann, plates 21-25; Cf. also, Eberhard's larger study, Das Toba Reich (Leiden, 1946); here, see Eberhard, Conquerors and Rulers, pp. 78-85.

33 Herrmann, plates 32-33; see also Lattimore, Studies in Frontier History, pp. 519-921; and Eberhard, Conquerors and rulers, pp. 92-102.

34 Herrmann, plates 26-31; Eberhard, pp. 87-88, citing A. con Gabain, "Steppe und Stadt im Leben der altesten Türken," Der Islam XXIX/1 (Berlin, 1949), pp. 30-62.

35 Lattimore, Studies in Frontier History, p. $242 \mathrm{ff}$. 
pastoral existence, but in actual fact the rhythm of life for the nomads of Inner Asia was complex and could not be described apart from the forests, deserts, oases, and agricultural communities on the periphery of the Eurasian steppe. On the steppe there was an unending struggle for balance and adjustment between differing economic interests, social groups, and political complications. And in times of major conquests, the rate of social change in the fringe areas between the steppe and the other geographic regions accelerated. ${ }^{36}$ In every case of social change, these transitional zones between the desert and the sown played a decisive role. But one does not find a straight line of evolution from the patriarchal clan society of the steppe to a transitional stage of feudalism in a conquered territory, and finally, to an imperial cen. tralized system. Lattimore prefers to consider the alternate periods of concentration and dispersion among the nomads as proceeding in spiral fashion, implying that each new era of concentration brought with it some improvement over the previous such period. ${ }^{37}$

But in spite of this spiral and the variety of the competing economies around the steppe periphery, Lattimore reminds us that the dominent landscape was that of pastoral steppe where, in the absence of modern industry, no social organization was possible except pastoral nomadism. And while nomads often became a part of the societies on the steppe periphery, new recruits also continually took up the steppe economy, leaving behind the Siberian forests or marginal agricultural tracts, for the steppe economy was capable of becoming entirely self-sufficient. Thus, the most important agent in Lattimore's analysis is the nomadic chief who has the option to build contacts with the periphery or to ignore it. It was the marginal areas, however, that permitted or favored change and hence... "prevented history from stagnating." In short, the marginal areas controlled the impulses for dispersion and concentration. As an example, Lattimore reminds us that Jenghiz Khan, like his father, held a title as 'lord of the marches' for the Chin or Juchen Dynastry which the Mongol Empire replaced.

A factor of paramount importance also in the cultural ferment on the steppe in the view of Lattimore was the fact that steppe nomadism, though highly specialized in the rearing of horses, also demanded a certain versatility, independence, and initiative in the individual which provided a sound prepa-

36 Ibid., 243-248.

37 Ibid., 251-252; 253-258. 
ration in the event of rapid change. As a test case of his multi-trained steppe nomad, Lattimore points to the example of the Orkhon Turks of the eighth century who, on the one hand, practiced or patronized irrigated farming in Outer Mongolia and also grew wealthy by controlling and investing in longdistance commerce such as transporting sable and squirrel pelts from the Siberian forests to the Chinese cities. Finally, Lattimore reminds us that 'horse nomads' could convert to military mobility without any increase in costs' and few changes in their way of life. For the agriculturally-based society, not only did the costs of conversion to a war economy come high, the damage the nomads could easily inflict on the settled populations and irrigation systems could destroy agriculture altogether and hence the main economy of a state. The converse was not true; the nomad often had nothing to lose but a tent made out of hides and a few sheeps.

In an essay on 'Frontier Feudalism'38 in 1954, Lattimore clarified his view of the rhythm of conquest of the nomads. Building upon his earlier observations that a hypothetical 'pure nomadism', though nonexistent, would be completely independent from the diversified fringe of the steppe, he places the ultimate volition to attack or not to attack in the hands of the tribal leader. Rather than rely on a rigid division of nomadism into Tibetan, Mongol or Turkish types as does Eberhard-Lattimore notes that Eberhard failed to mention the forest nomads and also to show that there were Turkish tribes in all three categories-Lattimore considers that the steppe federations varied in the percentage of sheep, horses, yaks, camels etc. they tended depending on the region and the historical situation. Although to my knowledge he nowhere structures his system of concentration, invasion of settled civilization and later dispersion, Lattimore would perhaps see the mechanism thus:

a. A leader of an almost purely nomadic group, on the basis of Lattimore's maxim' a pure nomad is a poor nomad is a hungry and daring nomad', increases the size of his ulus by victories over neighboring tribes whether nomadic or oasis-oriented;

b. The size of the troop of armed and mounted warriors at his command convince the' lords of the marches' serving China that their best interests will be served by switching sides;

38 Ibid., 515-540. In this essay, the role of the maternal uncle as peacemaker and protector of the wife's rights is developed. It is clear that under Hsiung-nu pressure a number of Han generals elected to serve the nomads. See, for example, the account in Watson, Grand Historian of China, p. 166. 
c. When the border buffer areas go over to the nomads and the crops are trampled under the hooves of the horsemen, the settled society quickly capitulates;

d. Thereafter, the nomadic leader converts his tribal control into military control over the agricultural state in three stages:

i. placing garrisons at strategic locations deep within Chinese territory but ruling the state and collecting taxes basically with the aid of the Chinese 'gentry';

ii. Clan leaders are settled on the borders with their followers who are supposed to continue the pastoral life while the chiefs are given Chinese border fiefs to augment their incomes;

iii. Deeper in the steppe and near to the oases, the khan maintains more distantly related and associated tribes, keeping their leaders within his orbit of power by rich gifts and the assignment of lucrative trade privileges and fiefs in the oases;

e. This process was reversed whenever upstart sub-chiefs or peasant revolts begin to dismantle the system. Eventually the tables are completely turned with the following result:

i. Former garrison troops and courtiers may withdraw, be slaughtered, or become integrated by marriage or service into theranks of the gentry;

ii. Nomadic chieftains possessing border fiefs may serve the new Chinese regime as march lords or else withdraw;

iii. The distant clans may hold on to their gains deep in the steppe, give them up to the retreating khan as a refuge or become once again greatly dispersed.

With some embellishments here and there, we have essentially Lattimore's two complementary forms of 'frontier feudalism'. In the first type, the nomadic confederation gains the upper hand; in the second type, the Chinese reassert themselves but never abandon completely the nomadic component of their state in the border zone. ${ }^{39}$

Clearly then, in the view of those Sinologists such as Lattimore, Eberhard and Köymen, who have concerned themselves with the steppe and fron-

39 Laftimore, Studies, pp. 533-539. 
tier areas within the orbit of Chinese civilization, the Turkic peoples had experienced almost 2000 years of intimate contact with China and the oases of Central Asia prior to the movement of the Seljuks into the central lands of Islam. At the center of Turkish nomadic life was horse breeding and the pastoral economy, but the environment of the steppe offered wide experience additionally in many types of agriculture and commerce. In particular, certain clans providing leadership for the periodic formation of large tribal confederations were greatly skilled in diplomacy, coordination of economic life and in military leadership. Finally, we have reviewed and discussed two complementary theories about the process by which a pastoral nomadic confederation transforms itself into a powerful empire basing itself partly on the eases of Central Asia and partly on the irrigated farmlands of Northern China.

\section{Who Were the Oghuz and What Pressures Drove Them Westward?}

On the basis of conclusions arrived at by James Hamilton after the careful sifting of Chinese, Eastern Turkic and Byzantine sources, ${ }^{40}$ scholars now are in a better position than previously to understand who the Oghuz Turks were prior to their appearance in Islamic sources. Furthermore, the Islamic sources have recently been closely scrutinized by such scholars as Sümer, Köymen, Bosworth, Kafesoğlu and Turan. This spurt of activity among Turkologists and Sinologists has added a great deal of new and specific information about the mechanisms of Turkic migrations into Western Asia and into the Muslim heartlands,

In the fifth century source materials attest to the grouping together of "Ten Uighur" clans which belonged to that group of tribes which the Chinese designated by the term T'ie-lo (> Tägräg; mod. Turk., Tekerlek, i. e., the peoples possessing large-wheeled wagons). The term Uighur itself probably, as in the case of the Tu-ku mentioned above, was the name of the largest orleading clan of the particular confederation and hence, as was the practice on the steppe, it gave its name to the entire confederation. Further than this, however, Hamilton considers, on the basis of good linguistic evidence, that the term 'Uighur' derives from an older Turkish expression Oghush signifying 'ally' or 'clan' which may also take another variant in the seventh century of 'Oghuz' (Thus, Oghuš > Uighur > Oghuz). As a result of political struggles in the fifth and sixth centuries during the formation of the T'yu-Kyu empire, some clans of the 'Ten Allies' (On Uighur) moved westward from Mon-

40 J. Hamilton, "Toquz-Oguz et on-Uygur," Journal asiatique cel/1 (1962), pp. 23-63. 
golia to the steppelands between the Aral Sea and the Northern Caucasus and contributed in the sixth and seventh centuries to the formation of the medieval Turkic states of the Khazars and the Bulgars. ${ }^{41}$ The memory of the "Ten Uighur" lingered on and appeared in the Turkic inscriptions on the Orkhon river (mid-8th century), in Rashid ed-Din's chronicle (early 14th century) and elsewhere. The official chronicle of the Chinese Souei Dynasty (581-617 A. D.)record that the T'ie-lo tribes still remaining in Outer Mongolia were attacked by the T'yu-Kyu confederation at the beginning of the seventh century, their wealth confiscated and their leaders killed. This repression sparked a revolt against the T'yu-Kyu by the T'ie-lo peoples in the Altai region.

The eastern T'yu-Kyu confederation, under a combined attack of a Chinese and Uighur force about the year 630 A. D., broke up and thereafter, under the leadership of the Uighurs ( a remnant of the former 'Ten Uighur?), a new grouping of tribes known as the "Nine Oghuz" assumed control of Outer Mongolia. ${ }^{42}$ By the mid eighth century, according to the Orkhon inscription celebrating the reign of the Uighur Qaghan Bilga (747-759 A. D.), the Nine Clans, i .e., the Dokuz Oghuz, had put an end to the rule fo the T'yuKyu entirely. ${ }^{43}$ In the opinion of Bosworth, the Dokuz Oghuz, having thus lost one major reason for their cohesion, began ot lose it as they incorporated defeated peoples into their federation while moving westward. After their decisive defeat by the Kirghiz in 840 , the Dokuz Oghuz, in any case, were forced to leave Outer Mongolia whence they, under the leadership of the Uighur clan, occupied the oases north and south of the Tien Shan, that is, Western and 'Chinese' Turkestan. ${ }^{44}$ Other clans of this Oghus confederation, now occupied the region between the Caspian Sea and the Aral Sea, a region which had already been occupied, according to Muslim sources, by Turkish tribes of the T'ie-lo (Western T'yu-Kyu?) confederation earlier. ${ }^{45}$

To recapitulate, the Oghuz Turks, to whom the Seljuk and the Osmanli Turks trace their origin, had served in the T'yu-Kyu Empire of the sixth and seventh centuries and again in the Uighur Confederation known as the Dokuz

41 Ibid., 48-50.

42 Ibid., 24-25, 29-29; Cf. also, Liu Mau-tsai, Die chinesische Nachrichten zur Geschichte der Ost-Türken (T'u-küe) (Göttinger Asiatische Forschungen, vols. 10-11 (Wiesbaden, 1958) -not available; C. E. Bosworth, The Ghaznavids (Edinburgh, 1963), p. 210, places the collapse of the Eastern T'yu-Kyu almost a century later.

43 Hamilton, pp. 29-30.

44 O. Lattimore, Pivot of Asia (Boston, 1950), pp. 122-123.

45 Hamilton, p. 30 and Bosworth, p. 211, for a slightly different version. 
Oghuz up to the middle of the ninth century. Thereafter, the leading tribe of the Dokuz Oghuz, which actually went by the name 'Uighur', occupied and Turkified the oases of Eastern Turkestan (Sinkiang), eventually becoming subjects of the Kara Khitay in the twelfth century and of the Mongols in the thirteenth century. The remaining tribes of the Dokuz Oghuz spread over Central Asia and the steppe from the Volga and the Caspian to the Oxus. The region between the Oxus and the Caspian served as the future starting point for the Seljuk infiltration and invasion of the central Islamic lands.

Meanwhile, at the time of the breakup of the Uighur power, and contributing to it, the Ch'i-tan (Kitay, hence Cathay in Western sources), a Mongol people who had dwelt in southern, Manchuria and who had served the T'yuKyu and Uighur rulers from the 6th to the 9th centuries, began to form a powerful new confederation. By the beginning of the tenth century, the Ch'itan had established their clear hegemony over northern China, Mongolia, Manchuria and the adjacent steppe and thus founded the Liao Dynasty (9071125 A. D.). ${ }^{46}$ The Ch'i-tan rulers, in accordance with traditional practice, forced the reorganization of captive tribes under their control, placed Ch'i-tan leaders the new tribal units and assigned various tribesmen to guard units in the ordo, the seat of the Kagan. ${ }^{47}$ If we study the movement of the Dokuz Oghuz westward with the knowledge that a strong centralized Mongol power, the Liao, had taken possession of the traditional eastern grazing grounds of the Oghuz, we shall have a clearer understanding of the pressure upon the Oghuz to seek pasturage and security in the Islamic lands. Doubtless wishing to escape the destruction of their traditional tribal units and to avoid the onus of serving under their former Mongol vassals, the remnants of the Dokuz Oghuz had pushed out of the Orkhon basin. In Transoxiana, the Oghuz fought with and displaced the Pechenegs who later appear on the Ukrainian steppe to harass the Kievan Rus. ${ }^{48}$

46 Lattimore, Pivot of Asia, pp. 122-128; and F. Sümer, "Oğuzlar", Islam Ansiklopedisi IX (1962), pp. 378-379 citing also, H. N. Orkun, Eski Türk Yazutları (Istanbul, 1940).

47 The basic study of the Liao period of Chinese history which is contemporaneous with the Seljuk history of the Near East has been prepared by Kral Wittfogel and Fêng Chia-Shêng, History of Chinese Society, Liao (907-1125) (Philadelphia, 1949).

48 For details, see F. Sümer, "X. yüzyılda Oğuzlar", D. T.-C. Fak. Dergisi XVI/3-4 (1958) pp. 136-138. It is interesting to note that W. Barthold, in his article on the "Kara-Hitaylar", (Islam Ansiklopedisi VI, p. 273) calls attention to the enmity between the Turks and the Mongols as a factor in the westward movemer.t of the Turks. Fuat Köprülü, by contrast, in his monumental study, "Osmanlı Imparatorluğunun etnik menşei mes'eleleri", in the Türk Tarih Kurumu Belleten VII/28 (1943), considers that population pressure impelled the Turks into the lands of Islam. 
Before leaving the traditional 'Far Eastern' steppe environment of the Turks, it is important to glean some political details from the Liao (Kitay), who were contemporaneous with the Seljuks, in order to clarify the later political activities of the Oghuz and the Jenghizid Mongols. Today it is customary to look to the West for political and military innovation, but in medieval times, innovation often came from the east. Contrary of the generally accepted theory that the nomadic or semi-nomadic conquerors of China (e. g., the Ch'i-tan, Jurchen, Yüan (Mongol), etc.) were readily absorbed by the Chinese, Wittfogel and Fêng have sought to demonstrate, in their important study of Liao Society, that the process of acculturation between steppe nomads and settled agriculturists or townsmen was quite slow and complex. Looking closely at the Liao-Ch'i-tan Society, they have shown that:

a. As the Ch'i-tan victory over the Chinese was only partial, basically north of the Yellow River, they maintained the center of their military and administrative power in their former tribal area (Northern Jehol) (Cf. with the Arab retension of their desert bases in Umayyad times);

b. The rulers were in close contact with the Chinese, but they never abondoned their tribal political and military organization nor their former secular traditions or religious beliefs;

c. The tribal organization continued to be more than an administrative unit because the mass of the Ch'i-tan continued their pastoral life;

d. The Liao political structure and economy was dual in nature; there was a separate administration and taxation for the pastoral and the agricultural economies and the Ch'i-tan pastoral economy supplied the basic needs of the army and the government (the Kaganate).

e. Key political and military posts remained in Ch'i-tan hands and military secrets were never shared with subject peoples;

f. The Ch'i-tan rulers, to the end preferred their own pastoral food including yoghurt and kumiss and counted their wealth in terms of horses;

g. When the Liao or Kitay were forced to retreat from China, a remnant took control of the oases from the Oxus to the Gobi desert and established the powerful state of the Kara Kitay (1134-1211). Jenghiz Khan and his son, Ogatai, drew upon the political experience of the Kitay when they laid the foundations of the Mongol Empire. This adaptation came about through the good offices of the Ch'i-tan nobleman, 
Yeh-lü Ch'u-ts'ai, chief advisor of Jenghiz and his son, after the Mongol conquest of the Kara Kitay in 1211. (See the plates of Herrmann, pp. 38-40.)

h. The Liao perfected the striking power of the cavalry two centuries before Jenghiz Khan by adding to the traditional mobility and striking power strict discipline, weapons training and 'clock-like' military organization. In addition, non-tribal foot soldiers and technical troops were made a permanent and important part of the army.

i. The Ch'i-tan ordo (ordu) initially appears to be synonomous with the khan's household including an elite guard of Ch'i-tan and carefully selected foreigners. Later this central ordo served as the prototype for a number of ordos or elite guard regiments and their supporting counties or prefectures around the empire of the Liao. The Mongols in the are of Jenghiz applied the term ordo to the four main divisions of the Empire and to other extraordinary military or political formations.

j. Finally, by reference to the Liao law code of T'ai-tsu (907-947), founder of the dynasty, we may discern legal principles which doubtless express tribal customs formulated on the steppe many centuries previously. Thus, for example, a person who insulted a superior or disobeyed his parents was threatened with death by torture, a law thus reflecting a strict hierarchical mode of life typical of Turkic peoples from that time until the recent Korean War (1950-1953). ${ }^{49}$

This brief excursus into Liao political history may serve as an indication of the state of political and military development of the Turks on the eve of the Seljuk invasion of the Islamic heartlands.

\section{How Was Economic and Political Power Reinforced Culturally?}

Another important aspect of the pre-Islamic background of the Turks also deserves some mention here: n,otably their religious and ethical background. To discuss the conversion of the Turks to Islam without some understanding of the prior ethical state of the steppe dweller would be most inadequate for our purposes here, for it is the ethical underpinnings which make this examination of'the nature of 'Turkish power' more intelligible. Thanks

49 Wittfogel and Fêng, pp. 1-25; 505-537; 465-467; see also on the Mongol yasa, V. A. Riasanovsky, Fundamental Principles of Mongol Law, (Tientsin, 1937). 
to the studies of Lattimore, Eberhard and others we have dealt in considerable depth with economic reasons and importance of maintaining a hierarchical and disciplined life on the steppe. Here we shall now seek out the ethical and cultural aspects of that life which serve to re-inforce the political and economic patterns and necessities.

At the heart of the Turkish ethical system lay shamanism. In fact, even after the conversion of the Turks to Islam a number of shamanistic practices continued to play a part in the life of the Turks. The shaman of a clan or tribe was usually a native of that tribe. He was generally selected by the senior shaman from among those local boys who showed themselves to be contemplative, intelligent and withdrawn. The elder shamans would then teach him their art and the novice in turn could add his own embellishments and variations as he matured. The shaman performed the essential role of communicating directly with the gods above and the evil spirits below. He gave to his tribal members what has been termed 'psychic integrity' the assurance that a member of their own tribe could intercede for them in critical circumstances produced by inhabitants of the unseen world. Thus, in matters of birth, death, marriage, warfare and tragedy, the shaman was called upon to speak a good word..$^{50}$

The basic ritual of the shaman often began with the staging of some 'miracle', such as walking on hot coals or the use of ventriloquism. This stage was followed by an ecstatic experience wherein the shaman might fall to the floor or the earth, face downward, in a trance. The third phase was not visible to mere mortals as it entailed the ascent of the shaman to heaven or his descent to hell to intercede for his tribesmen. Sometimes the shaman became 'possessed' by spirits and his body writhed in pain. Upon coming out of his trance, the shaman might relate to his audience the series of incidents which befell him on his journey. Often a superb horse was symbolized as the means by which the shaman was transported to heaven. Among the Turks, the drum in particular, but other musical instruments and singing on occasion, served as a 'celestial bridge' to prepare the way for an ethereal flight or communion with the spirits. In the other world everything was opposite to its counterpart on earth; also, the recently deceased were greatly feared while the ancestors were revered and accessible by means of the shaman. The bow and arrow too served as symbols of celestial flight.

50 See Mircea Eliade, Shamanism (Bollinger Series, 76) (N. Y., 1964), pp. 508-511 and passim. 
Perhaps most important in terms of the Turkic authority structure, every head of a family was recognized as the head of the domestic cult and hence maintained custodianship over the family drums. The implication here is fundamental: the family patriarch could communicate with the spirits to reinforce family discipline and his authority. Symbolically the weapons of the warriors served as a defense against evil spirits in the struggle for life, health, fertility and the world of 'light' against death, disease, sterility, disaster and 'darkness.' Thus shamanism, to the extent that it presented the world as the place of struggle between heroes and demons, became closely related to the development of epic literature among the steppe nomads. ${ }^{51}$

As the art of the shaman depended greatly upon the personality, intelligence and personal magnetism of the individual shaman, it is not surprising that the influence of the shaman fluctuated with time and place. A divergence in lore or ritual or an adverse message from the spirits through direct contact or devination could bring about radical changes in a given tribe. As to the difference between shamanism and a revealed religion, Wach reminds us: "The essential difference between religion and magic is the fact that the former recognizes the subjection of man to the supernatural which he worships, while the magician tries to impose his will upon the gods by means of conjuration. Magic, that is, shamanism, required an intercessor; religion, a prophet". 52

Even after the conversion of the Turks to Islam, shamanism lived on in three main guises:

a. as epic literature, oral or written, mainly in verse form, passed on by the meddah (storyteller) or the âşik (minstrel):

b. as mysticism in certain T.urkish dervish orders:

c. as the bagi $i j i$ (sorcerer), the Islamized shaman.

(Cf. also synonyms and related terms in Turkish: büyücü, üfürükcü, falci, okuyucu, cadu, afsuncu, irkil, kam (archaic term for shaman). ${ }^{53}$

The Chadwicks in their classis study of the origins of literature devoted a section of their work to the 'Oral Literature of the Tatars'. ${ }^{54}$ The themes of

51 Eliade, pp. 4, 135, 152, 205, 247, 503-504, 508-511.

52 J. Wach, Sociology of Religion (Chicago, 1944), pp. 73 and 350.

53 Cf. the article 'Büyü' in M. Z. Pakalin, Osmanlı Tarih Deyimleri ve Terimleri Sözlüğ̈̈ I (Istanbul, 1946), pp. 250-251 and also, Wittfogel and Fêng, pp. 216-218, for details of shamanism, its taboos and charmas, among the Kitay.

54 A. M. and N. K. Chadwick, The Growth of Literature, 3 vols. (Cambridge, 1940). 
the heroic poetry include raiding, theft of herds, single combats, revenge of injuries, wooings and marriages, the birth and remarkable childhood of heroes, sports and long adventure-filled journeys, typical events in the life of the steppe. The primary virtues extoled are courage, loyalty and generosity and of prowess against enemies. The personnel of the poems are generally aristocratic and the women often prove to be as heroic and militant as the men and sometimes more savage. Feasting on a grand scale demonstrates the generosity and success of a hero or ruler. Often the hero appears as a law unto himself as long as his exploits bring victory and booty, yet the hero, in spite of a certain coarseness, exhibits an air of decorum and self control. The journey of the hero through strange lands and his struggle against evil spirits are reminiscent of the flights of the shaman to heaven or the underworld. Behind the desperate and hopeless undertakings of some heroes lies the relentless will to survive in the often harsh and unpredictable economic conditions of steppe life. Here again we are reminded of Lattimore's platitude: 'a pure nomad is a poor nomad, is a hungry and daring nomad.' Among Ashan interesting part of the non-heroic literature of the steppe, we find that riddles play an important role. Two heroes seeking the hand of a fair maiden may be given riddles by the prospective father-in-law as a test of their intelligence or reasoning powers. Finally, in all of the literature of the steppe peoples the horse figures prominently to the point of speaking to the hero and sharing in his heroic deeds. ${ }^{55}$

Once again we are led to conclude that, as with shamanism, the oral literature served to reinforce tribal lotalties, virtues and discipline. To translate this cultural influence into practical affairs of political significance requires the examination of two institutions: the Mongol concept of nukur or 'declaring one's self a follower' and the Turkic term bahadir (bagatur) or 'knight, follower, hero'. According to Lattimore, the Mongols built larger units after the defeat of other tribes by applying three different methods, each of which, in its own way, helped the defeated tribe to save face: ${ }^{56}$

i. By extending blood kinsbip on the basis of anda or 'sworn brotherhood' which required the acknowledgement of the ancestors of the conquering tribe;

ii. By 'collective subjection' (unagan bogol) to the conquering tribe, a practice which permitted the subject tribe to keep its clans intact and to hold property;

55 Chadwick, pp. 52-79, 107-126, 140-153, 192-204. Df. also, A. Tietze, Tge Cuman Riddles (Leiden, 1969).

56 Lattimore, Inner Asian Frontiers, pp. 535-536. 
iii. Finally, by permitting young warriors of a defeated tribe to 'declare themselves a follower (nukur)' of the new leader.

This latter method of changing allegiance was the most drastic and disruptive of previous clan structures because to become a nukur, one must break with his former tribal ties and submit to the will of the new chieftain. In this manner, the instilling of heroism in the young men had a natural outlet when the young warrior could join an elite corps of a newly-forming steppe confederation.

The Turkish equivalent of the nukur practice appears to have been the position of the bahadiror alp (Cf. other Turkish synonyms such as kahraman, yiğit, cengâver). While according to Köprülü, ${ }^{57}$ the institutional history of bahadir has not yet been worked out fully, we are aware of the concept of an elite guard serving the various khans and kagans of the steppe empires as far back as T'yu-Kyu times. Moreover, the members of the elite 1000 man guard unit set up by Jenghiz. Khan were called bahadir. This term also crept into the titles of the rulers who were under Mongol or Eastern Turkic influence, but was only rarely used among the aerly Ottomans. Nevertheless, the presence and the efficacy of such an elite guard institution and of its fundamental association with the basic political and ethical mores of the steppe peoples, regardless of the terms used to describe it, was not lost to the Ottomans!. While touching here upon the longevity of such an institution as an elite guard unit on the steppe and in the Chinese orbit, it would also seem appropriate to note the continuity of Turkic steppe titles among the Seljuks and Ottomans. Köprülü's excellent summary of the widespread use of the title 'Bey' indicates in another direction the impact of the steppe on Islamic society from the eleventh century on..$^{58}$

Before turning to the conversion of the Turks to Islam, one should give passing recognition to one other important literary work of the Turkish past, notably the Kudatku Bilig (The Knowledge Befitting a Ruler) a practical guide to ruling a kingdom written in Uighur by a chambarlain (hajib) at the court of Bughra Khan. In studying the literature of the Uighurs we are reminded of the crossroads nature of Eastern Turkestan where Manishaean, Nestorian Christian, and Buddhist communities long withstood the political and cultural pressure of Islam. ${ }^{59}$ By the late tenth century, however, Lattimore

57 Fuat Köprülü, art. "Bahadir”, Islam Ansiklopedisi II, pp. 216-219.

58 Köprülü, art. "Bey", Islam Ansiklopedisi II, pp. 579-581.

59 The great importance of the Kudatku Bilig to the Turkish literary and cultural traditions cannot be appreciated in this brief sturvey. One should read the excellent summary by $R$. 
concedes that Islam is beginning to dominate the 'oasis world' of Central Asia. In fact, he calls the Muslims the 'Protestants' of the oases as they were much more political-minded than, for example, the Buddhists. ${ }^{60}$

The Kudatku Bilig as en eleventh century Turkish political tract serves as a measure of the sophistication of the Turkish oasis leadership and as an indication of the extent of Islamization in Turkestan. The writer divides the Uighur society of Kashgar into three groups: the simple people (kara am); the servitors (tapukci) and government officials. The kara am consisted of merchants (satikci), peasants (taranci) and animal breeders (igdiş̧i). In the tapukci class were the seyyids ('alevi), the physicians (öteci), conjurers (apsunci) and astrologers (müneccim). )The government officials were comprised of the khan, the wazirs, the army leaders (su başi), the scribes (bitikci), the ambassadors (yol agasi ??, Cf. with Ulağ) and the guards (kapukci). ${ }^{61}$ The conflict between the old shamanist ways and the new Muslim science is illustrated in the Kudatku Bilig when the ruler is advides to respect the physician because he heals with medicine, but also, to honor the shaman who heals with a talisman. ${ }^{62}$

\section{E. The Seljuk Conversion to Islam and Some Questions of Turkish Power in Western Asia}

As the westward probing Oghuz entered the Islamic environment of Transoxiana in the latter half of the tenth century, they appeared to be well led and unified. They are known to have displaced the Pechenegs, driving them to the northern shores of the Black Sea. Evidence also points to elements of the Oghuz having raided the Khazar state, possibly leagued with the Ki-

Rahmeti Arat, in the article 'Kutadgu Bilig', Islam Ansiklopedisi VI, pp. 1038-1047. Facsimile editions of the Vienna, Fergana, and Egyptian manuscripts were prepared in Istanbul, 1942 and 1943. Owen Lattimore in his book, Pivot of Asia (Boston, 1950), a study in depth of Sinkiang (Eastern Turkestan), quotes extensively from H. Vambery's Uigurische Sprachmonumente und das Kudatku Bilik (Innsbruck, 1870); see especially pp. 241-258. R. Seşen, in his "Eski Araplar'a göre Türkler", Türkiyat Mecmuası, XV (1969), pp. 11-36, has assembled some early Arab opinion about Turks from such sources as Jahiz's Menāḳib al-Turk.

60 Lattimore, Inner Asian Frontiers, pp. 180-181.

61 Lattimore, Pivot of Asia, pp. 242-245, citing Vambery, Uigurische Sprachdokumente, pp. 5-6.

62 Lattimore, citing Vambery, pp. 136-137. This interesting passage urging the ruler to honor both the physician and the shaman was the subject of an article by Professor R. Rahmeti Arat, "Kutadgu Bilig'de tabipler ve efsuncular ile münasebet hakkinda", Ülkü VII /46 (1936), pp. 280-292. 
evan Rus, about $985 .{ }^{63}$ They also had sharp encounters with the Karluk tribe. It is not clear whether or not the Oghuz remained under the leadership of one Yabgu (leader of a confederation) up to the early years of the eleventh century. ${ }^{64}$ What seems clear is that there was much strife among the leading families and their followers over the supreme leadership of the tribal confederation. Although, as has been emphasized above, certain families among the Turks always provided tribal leadership, controversy often developed over whom should succeed a given ruler. Was he to be succeeded by his own offspring only, could brothers and sisters of the leader lay claim to the supreme headship for themselves or their children? The succeeding history of the Turks was bedeviled vith this question. The Seljuks accepted the broader family principal; the Ottomans, doubtless because of events in their early history to be touched upon at the end of this paper, evolved a system of executing members of rival, parallel lines. Professor Bernard Lewis, in an important paper which anticipates some of the points in this essay, has discussed the important problem of dynastic succession among the Turks. ${ }^{65}$

In any event, according to legend, a certain leader known by the name of Seljuk, who had inherited the rank of Subaşi $(\sim$ commander of the tribal forces) from his father, broke off relations with the Yabgu. Later his son, Israel Arslan, led his Kinik family and the Oghuz clans following their leadership into Khorasan at the beginning of the eleventh century. At this time, we also

63 Many writers have dealt with the serni-legendary materials which give insight into the activities of the Oguz in the 9th to the 11th centuries. See for example, F. Sümer, "Dede Korkut Kitabına dair bazı mülâhazalar", Türk Folklor Araştırmaları II (Jan., 1952) and P. N. Boratav, "Dede Korkut Hikâyelerindeki Tarihi Olaylar ve Kitabın Te'lif Tarihi", Türkiyat Mecmuası XIII (1958), pp. 31-62. Understandably, the study of the tenth and eleventh century Turks has been popular in Turkey. Especially significart are the articles by Faruk Sümer, "X. Yüzyılda Oğuzlar", Dil ve Tarih-Coğrafya Fak. Dergisi XVI (Sept.-Dec., 1958), pp. 131-162, and M. A. Köymen, "Büyük Selçuklu Imparatorluğu'nun kuruluşu”, Ankara Üniv. Dil ve Tarih-Coğrafya Fak. Dergisi XV 1-3 (1957), pp. 97-191, XV/4, pp. 1-107, and XVI/3-4, pp. 1-66.

64 There has been some interesting disccssion about the relative position of Seljuk and of the Yabgu between Professors O. Pritsak and Cl. Cahen. For specific references to this scholarly difference of opinion, see Cahen's art. "Ghuz:", in the Encyclopaedia of Islam 2 II, pp. 11061110. Professor I. Kafesoğlu has also been very interested in the Seljuk family; among other items, see his "Selçuk'un Oğulları ve Torunları", Türkiyat Mecmuası XIII (1958), pp. 117-130 and the accompanying geneological chart, and his Selçuklu Ailesinin menşei hakkında (Istanbul, 1955).

65 A reliable account of these events is available in the careful study of C. E. Bosworth, The Ghaznavids, Their Empire in Afghanistan and Eastern Iran 994: 1040 (Edinburgh, 1963), espec. pp. 206-227 and 241-268. 
know that the Oghuz Turks under Seljuk family leadership accepted Islam of the Sunni persuasion and were henceforth referred to as Türkmen or Turcoman, thus distinguishing them from those Turks who remained loyal to shamanist beliefs. The Seljuks very early gained acceptance among their Muslim neighbors because of their prowess as fighters. They helped successively the Muslim Karakhanids, the Samanids, the Ghaznavids and the Khwarezmshahs against their non-Muslimıneighbors such as the the tribes previously mentioned and also the formidable Kitay. Nor did the Seljuks neglect their relations with the Caliphate in Baghdad which at the time was still controlled by the Buwayhids, those warriors from Dailam who followed the Twelver Shi'ite persuasion. ${ }^{66}$ It was indeed the relationship which the early Seljuks developed with the Caliph al-Qa'im and his successors which lent a certain legitimacy to the conquests of the Turks even though these relationships were seldom free of bitterness and rivalry. In particular, the defeat by the Seljuks of the Buwayhids and other smaller dynasties made possible the resurgence of traditional Islam in the last decades of the eleventh century. ${ }^{67}$

Without here going into a detailed description of the Seljuk takeover of the Near East in the eleventh century, a task which has recently been so well done by a number of scholars, ${ }^{68}$ it is important nevertheless to call attention to the far-reaching changes in the Islamic Near East during the eleventh century and thereafter as a result of its penetration by the steppe peoples. As had repeatedly in the past, a powerful steppe confederation, this time the Dokuz Oghuz, had lost its inner cohesion, but one branch thereof, which was subject to the leadership of the Seljukids, accepted Islam, initially ingratiated themselves with their Muslim neighbors on the borders of Khorasan, and eventually, applying the time -honored tactics of the steppe, carved out an empire often with the encouragement of what we might term today the Sunni Muslim establishment. ${ }^{69}$

66 For a general discussion, see the article of Cl. Cahen, "Buwayhids", in E. I.2 I, pp. $1350-1357$.

$67 \mathrm{See}$, in particular, G. Makdisi, Ibn-Aqil et la résurgence de l'Islam traditionaliste au XIe siécle (Damascus, 1963) and also the interesting turn of event when the Sultan tries to marry the Caliph's daughter; Makdisi, "The Marriage of Eughril Beg", Internat'l J. of Middle East Studies (I. J. M. E. S.) I (July, 1970), pp. 259-275.

68 See the preceding footnotes, and also, the excellent elucidation of the main events in Seljuk history by Cl. Cahen in K. Setton, M. Baldwin, R. L. Wolff, and H. W. Hazard, eds., The Crusades 2 vols. (Phila., 1955, 1962) and a more recent elaboration of Cahen's ideas in Pre-Ottoman Turkey (New York, 1968).

69 Makdisi, loc. cit.. 
We have so far called attention to three major events of the eleventh century: the movement of the Seljuks into the central lands of Islam, the Islamization of a large block of Turks, and the rapid conquests and the legitimization of the Seljuk rule. Perhaps of decisive importance, however, for the first time large areas of the Near East and adjacent regions became Turkified. Apart from Eastern Turkestan, settled by the Uighurs, we know that the following regions absorbed large Turkish populations: Khwarezmia, east of the Caspian; the Kipchak (modern Ukrainian) steppe; Azerbaijan; many districts within the confines of Iran; certain regions of the Caucasus; Northern Iraq and, after the Battle of Manzikert, much of Asia Minor. Clearly there was also more than one wave of Oghuz Turks to swell the ranks of the initially penetrating Seljukids. Köprülü gives credit chiefly to a population explosion as an explanation of this glut of steppe dwellers. ${ }^{70}$ While not denying this out of hand, in the view of this writer, the nomadic way of life itself and the basic nutritional value of pastoral foods gave to the invaders a much higher rate of natural increase and subsequently a higher natural rate of survival than the diet of the average town dweller of the Muslim Middle Ages. There is no doubt whatsoever that the plague ('bad air') and other mass epidemic killers affected the nomads much less than it did the town dwellers, a fact we know from eyewitness accounts of the Ottoman invasion of Eastern Thrace about 1354. In the Near East today, we have positive proof of the efficacy of the pastoral diet which was widely accepted throughout the area, influencing also Eastern Europe with the coming of the Ottomans and Western Europe and North America today. This new range of steppe cuisine in the Near East probably dates from the eleventh century, but whatever was not adopted then, came in with the second major wave of Turks just before, during and after the Mongol conquests in the thirteenth century.

In this essay, we have now come full circle, starting with the 900th anniversary of Manzikert, we have sought answers to the questions 'whence and who are the Turks?' by seeking wisdom 'even in China.' We asked the rhetorical but basic question: How were the Turks able to conquer and control vast and important territories in the central lands of Islam from 1071 until the beginning of this century? If we look at the Turkish social structure even today, we can come up with a partial answer. The Turks have maintained,

70 See Fuad Köprülü's most impressive article, “Osmanl Imparatorluğu'nun Etnik Menşei Mes'ilileri”, in the T. T. K. Belleten VII /28 (1943), pp. 219-303. To my knowledge, this most fundamental study of the origins of the Ottomans has not yet been translated into a Western European language. 
by and large, a hierarchical system of authority, based on special skills and nurtured in a patriarchal family system, for thousands of years. Moreover, the old Turkish elite, partly because of this authoritarian system, partly because they allowed for mobility in the system, and partly because the old Turkish families possessed at first herds and flocks and finally large estates, these family responsibilities provided the opportunity for energetic scions of a given family to become experienced leaders and managers of their own family holdings. It was thereafter only a small step to become headers of warriors and whole countries. But must we indeed turn to the pre-Islamic history of the Turks to understand Seljuk and Ottoman history? It is the opinion of this writer that we must.

For many years, Islamic scholars have attempted to answer most questions of Turkish history by seeking answers almost exclusively within an Islamic Arab or Persian context. This Islamic approach may have been dictated by a certain bias of Western European and American historians to view most aspects of nomadism or the steppe environment as at once too barbaric and unintelligible. Turkish historianas before the formation of the Turkish Republic were also strongly influenced by this bias. Let me hasten to say, that it is of course essential to understand the Islamic environment in which the Seljuks and the Osmanli thrived. But in matters of large scale political organization and in the management of a complex economy, the Turks had no real peers in the Middle East once they had broken the power of the Italian city states. This sweeping statement does not deny indeed that the 'Turkish system' deserves its share of careful criticism as do all political systems. This point of view also would not deny that many brilliant discoveries have been made during the past century of Islamic scholarship. Sometimes the greatest gems of scholarship are not widely circulated. One suc hitem is Professor Cahen's study of the adverse effect on Islamic political institutions produced by illiterate Turkish generals siezing power from the Abbasid Caliphs in ninth century Baghdad. ${ }^{70}$ In the Seljuk and the Ottoman states, for example, as Wittek has often pointed out, there was always a state of tension between tribal elements and the purveyors of the traditional agricultural and cityoriented high Islam. The history of Rashid ed-Din doubtless best portrays the tension between pasture-hungry Mongol troops and the traditional villagers

70a "Les Facteurs economiques et sociaux dans l'Ankylose culturelle de l'Ilasm", in R. Brunschvig, ed., Classicisme et Declin cultural dans l'Histoire de l'Islam (Paris, 1957), pp. 195215. 
of the Iranian plateau. ${ }^{71}$ But the view from inner Asia of the newly forming Turkish states of the Near East is different from the view found in Medina, Cairo and Damascus. Had the Arabs inherited a hierarchical sustem of authority capable of the inner dynamics and flexibility of the Turkish system, the course of Middle East history would have been quite different, in the Middle Ages and now.

To test whether or not inner Asian history supplies answers to some of the baffling questions of Turkish history, let us turn to some of the specific problems:

1. It is clear that the Turkic steppe nomad, in terms of mobility, fire power and invulnerability to attack, had a tremendous advantage over his agriculturist opponent; mobility in fact was the key to successful grazing of animals for the nomad. The nomad could render long-term damage to agricultural production in a very short time. The Seljuk, Mongol and Ottoman leadership was always aware of this potential. Tughril Bey, in his negotiations with the dignitaries of Nishapur, reminded them of their vulnerability, a point which hastened the capitulation of the city. The failure of the armies of Mas'ud of Ghazna to relieve Nishapur owing to their heavy baggage train and the difficulty of crossing the desert and steppe gives us a classic example of the advantages of even a relatively small and impoverished Turkic tribe over skilled conventional armies of the eleventh century Iranian frontier region. The Mongols, exercising far less restraint than did the Seljuks, laid waste a number of agriculturally advanced regions of Persia, obliterating the population and grossly reducing their revenues. The Ottomans during the early centuries of their existence were on both the giving and receiving end of 'scorched earth' policies. They did not hesitate to lay waste the lands of a recalcitrant enemy and carry his inhabitants off into slavery with the help of skirmishers (başi bozuk), Crimean Tatars and similar elements. But they also strictly forbade the molestation of peasant holdings within their own realm.

2. As regards the question of the knowledge of agriculture and of commerce among the steppe nomads, Lattimore and Von Gabain have settled this question through their intimate knowledge of the complex life of the steppe where tribal chieftains vied for control of the produce and trade of the oases

71 See the quotations from Rashid ed-Din and the accompanying commentary in I. P. Petrushevsky, "The Socio-Economic Condition of Iran under the Il-Khans", in J. A. Boyle, ed., The Cambridge History of Iran V (Cambrodge, 1968), pp. 483-537. 
and towns on the steppe periphery. One may even some day make a special case for the Oghuz as a tribal confederation receiving special tutelage in the ways of the oases from the Uighurs who controlled the agriculture and commerce of Turkestan.

3. We must lean heavily on the work of the above-noted Sinologists and ethnologists for an understanding of the functioning of Turkic elites. Clearly even the Turkic tribes maintained hierarchical relationships among themselves. Hence, 'noble' tribes exhibit a concentration of leadership skills which are necessary for the survival of large confederation such as the T'yu-Kyu, the Uighur or the Oghuz. Moreover, a lead tribe generally gave its name to an entire confederation thus acconuting for the subordination or disappearance of other tribal names. Lattimore's detailed description of the tremendous flexibility and adaptability of the steppe nomad in a rapidly changing social environment also corresponds favorably to our knowledge of the early Ottomans.

4. The conversion of the Seljukids to Islam has not been adequately explained. We have tried to show here that the economic necessities of horse nomadism provided a raison d'etre for a strict hierarchical and patriarchal type of life on the steppe. It is also clear that shamanism reinforced the discipline of the tribes and of the family. Among the steppe peoples, however, as is revealed in their epic literature, in the travel account of Ibn Battuta and elsewhere, the women played a very important role by comparison with their Muslim counterparts. But at the time of the conversion of the Seljuks to Islam, there appears to be a definite breakdown in traditional discipline among the Oghuz tribes. Could it be that the Seljuk leadership turned to Islam to reinforce the waning loyalties of an obsolescent system of tribal discipline? Or perhaps, were the Turkic women either becoming too powerful or else less attractive to their men as they began to take as wives and concubines the more sophisticated and supplient Muslim women? We do know, for example, that two out of the five rulers of the Kara Kitay (Western Liao) were women.

There is little doubt that the elite often accepted with circumspection the claims of the shamans. Is it to the decline in the influence of shamans, the loss of tribal discipline or the presence of other monotheistic faiths which helped to bring the Seljuks over to Islam? There was doubtless a combination of factors, including the willingness of the proselytizing Sufi dervishes to accept many pre-Islamic practices. 
Ibrahim Kafesoğlu has taken note of an interesting account of skepticism in high places when he tells of the encounter between a shaman and Ogatai, son and successor of Jenghiz Khan. ${ }^{72}$ In the encounter, a Turkish speaking shaman claims to have talked with the deceased Temuchin and Ogatai, who was strongly under Christian influence, asked the shaman what language they spoke together. The shaman confessed that he only knew Turkish. Thereupon, Ogatai held the shaman up to ridicule at court because his father only knew Mongol. Whatever the truth is behind the conversion of the Turks to Islam, it is clear that they so construed Islam that it served to reinforce the strict authority system of traditional steppe life, but Islam also appears to have hurt the status of Turkish women. Moreover, a sheykh of a dervish order often set up his own system of authority which sometimes ran counter not only to Ottoman authority, for example, but to the tenents of Islam.

5. We have discussed at some length in this article the mechanisms which might account for the rather sudden change in the grazing patterns and life styles of the nomadic Turks, everts sufficient to impel the nomads into the agricultural heartlands of China or the Near East. In the case of the Western Oghuz, it is clear from their tribal legends that at the very time in the late 10 th century when they were losing their inner cohesion, they were faced with very serious political pressure in Khwarezmia and Transoxiana. The path of least resistence apparently lay in the direction of the crumbling Samanid state. Here one might find pasture, booty, and employment as warriors. Clearly the chronicle of Baihaqi is the most valuable of all for depicting the poverty of the Seljuks as they first enter Khorasan. Also we gain from the same source a good indication of the keen intelligence of Tughril and Chagri as they offer to Nishapur (1038 A. D.) Seljuk protection for which the notables were asked to pledge reasonable taxes. ${ }^{73}$ One must, however, consider the question of original cause. Did the Seljuks indeed invade Khorasan or were they impelled to do so to ensure their survival against other encroaching political forces?

6. As the Seljuks settled in Fersia and Mesopotamia, it is interesting to see how quickly they come to terms with their new subjects, particularly the Persians, and then go about the business of ruling their farflung state with close relatives and a Persian bureaucracy. Similarly, the steppe nomads of

72 I. Kafesoğlu, "Türk Tarihinde Moğollar ve Cengiz Meselesi”, Tarih Dergisi V (1953), p. 133.

73 Bosworth, pp. 252-266; Köymen, "Büyük Selçuklu Imparatorluğu...”, D. T.-C. Fak. Dergisi XVI/3-4, pp. 1-66. 
inner Asia were ever adding new units of specialization to their confederations whether Chinese, skilled in irrigation or Tibetan infantrymen. They not infrequently used the Chinese or Uighurs for administrators. Well aware of new job opportunities, the Kuttab or bureaucratic class quickly flocked to the Seljuk banners when the Seljukid leadership showed itself wise and for the most part moderate. The Seljuks, possibly under Persian tutelage, were also quick to adopt the $i q t a^{973}$ system to maintain the tranquility of the army without too heavy a drain on the scarce coinage of the empire. In like manner, the Ottomans also soon learned to make excellent use of the skills of their Christian and Jewish subjects.

7. On the subject of special guard units surrounding the ruler, it is obvious that the practice had long been known to the Chinese and to the steppe nomads. It is probably true that an elitist steppe guard would not have received the sophisticated training which was accorded to pages in the Near East, a tranining so well depicted by Nizam al-Mulk in the Siyasetname. ${ }^{74}$ The rigorous training described in the Siyasetname must have influenced the manner of training of palace guards in Ottoman times. As to the question of when did it occur to the Ottomans to draft their Christian subjects, this idea could not have been a new one either to the steppe or to Islam in the fourteenth century. Historical literature dealing with the Liao (Kitay) and the Mongols often refer to the use of foreigners in the elite guard regiments long before the formation of the Ottoman state. Both Sultan Mahmud of Ghazna and Nizam al-Mulk, following the Ghazna example, believed in an ethnic mixture among the guards to ensure a competitive spirit and the safety of the sovereign.

Of particular interest, in the light of what happened to nomad rulers under the spell of Chinese civilization, is the observation of Nizam al-Mulk that the Turkmen (that is, the tribes) had already become an embarrassment to the dynasty in his day (late 11th century) because the clan chieftains had reverted to earlier patterns of raiding and grazing at the expence of the peasantry. The solution of the Wazir called for the drafting of the sons of the clan leaders into the page service of the palace to ensure their loyalty and attachment to the dynasty. ${ }^{75}$ Such a proposal served a double purpose: to Iranize tbe young beys and to hold them as hostages (rehin) to ensure the loyalty of the fathers.

73a For an excellent summary of the Iqta' system, see Cahen's art. "Iḳtā'," in E. I.2 III, pp. 1088-1091.

74 See The Book of Government (Siyäsat-name) of Niz̄äm al-Mulk, tr. by H. Darke, (London, 1960), pp. 103-104, 106-121.

75 Ibid., 
8. Ibrahim Kafesoğlu, by taking issue with the thesis of Turk-Mongol similarities and eternal friendship in his critique of the late Zeki Velidi Togan's book, Umumi Türk Tarihine Giriş $I_{,}^{76}$ opened up the question of ethnic relations on the steppe and the possible connection of these traditional relationships to historical events in the Near East. There is, in fact, much evidence that hostility or at least sharp rivalry had long existed between Mongols and Turks. In an oversimplified manner one might start with the onservation that the Turks helped to keep the Mongols confined to the forest regions north of the Gobi desert until the ninth century. One cannot deny, however, that these two ethnic groups had often joined the same steppe confederations in the past, wheter out of duress or self interest, and have exhibited many cultural features in common. In the Orkhon inscriptions as Barthold has pointed out, the Mongol (some say '] unguz) Kitay (later Liao) are several times mentioned as rivals and enemies of the Turks. Little wonder then that the Oghuz moved westward when the Kitay became dominant in Mongolia and China. One might also take as evidence of such enmity the murder of the Mongol envoys by the khwarezmshah just prior to the Mongol invasion of the Near East. As Kafesoğlu has aptly pointed out, did the Mongols bring so much destruction to a largely Turkish-ruled Near East out of love for the Turks?

Osman Turan in his important study of Seljuk times has also emphasized once again the terrible destruction and wanton waste of human and economic resources which the Mongols brought to the Near East in the thirteenth century. In his opinion it is wrong for modern historians to underestimate this terrible disaster. ${ }^{77}$ The Mongol leaders of Iran, known as the Ilkhans, also lent their support to Christianity and Shi'ism, a factor not meant to endear them to the Sunni oriented Seljuks of Asia Minor. ${ }^{78}$ Without wishing to slight the Mongols, it seems fair to conclude that the Oghuz, as inhabitants of the southern, more developed part of the Eurasian steppe, were, in the Middle Ages, far more advanced than were their forest-dwelling Mongol neighbors to the

76 I. Kafesoğlu, “Türk Tarihinde Moğollar ve Cengiz Meselesi”, Tarih Dergisi V/8 (Sept., 1953), pp. 105-136.

77 See VV. Varthold's art., "Kara Hitaylar", in I. A. VI, pp. 273-276. Regarding the terrible destruction of the Mongols, see Petrushevsky, loc. cit. and Osman Turan, Selçuklular Tarihi ve Türk-Islam Medeniyeti (Türk Kültürünü Araştırma Enstitüsü Yay. VII, Seri III (Ankara, 1965), passim. For a more moderate view, see B. Lewis, "The Mongols, The Turks and The Muslim Polity", Transactions of the Royal Hsitorical Society Series 5, Vol. 18 (1968), pp. 49-58.

78 For a summary of these Ilkhab attitudes, see the article by B. Spuler, "Ilkhans", E. I.2 III, pp. 1120-1123. 
north. In the presence of such economic or social disparities, one must conclude that ethnic rivalry indeed existed.

\section{F. The Dynamics of Early Ottoman State Formation}

In the preceding pages we have traced the origins and the development of Turkish political techniques in heir social context. Certain events and institutions have inevitably received emphasis at the expense of others, partly to illustrate a point of view and partly because of the strictures of space and time. In the final pages of this paper I should like to discuss, by means of a static model of Ottoman society, the dynamics of early Ottoman state formation. By the end of the fifteenth century, the Ottomans had developed a social structure which may be outlined as follows: ${ }^{79}$

I. The Sultanate (the Sultan and his Household including guard regiments, court poets and palace school)

II. The Vezirate (Grand Vezir, Divan and the principal bureaucrats Kuttāb)

The III. The 'Ulema (the religious, judicial and educational establishment)

Elite IV. The Erbāb-i Tīmār (Service Gentry' holding provincial estates and serving in the 'feudal' cavalry)

$5 \%$ V. The Sheykhs of the Tariqaat (Dervish Orders)

VI. The Tuccār (Merchants)

a. Muslim (from which group came the town notables (Ayan)

b. Non-Muslim (from which derived the Notables of the Millets)

VII. The Esnaf (Skilled Artisan Guilds)

a. Muslim (from which derived town notables)

b. Non-Muslim (from which derived notables of the Millets)

VIII. The Reaya(village-based peasantry)

Muslim and Non-Muslim (productive units for Hașș, Timars, Ziamets and the Millet aristocracy)

79 The writer first elaborated this structure in a paper read to the International Congress of Orientalists which met in Ann Arbor, Michigan (August, 1967). Thereafter, a more detailed account was presented to the first New Tork University Round Table on Turkish Politics and History. See Kortepeter, "The Islamic-Ottoman Social Structure: the Quest for a Model of Ottoman History;" see the regerence in note 5 , above. 
IX. The Aşiretler (steppe and mountain-based tribes)

X. The Müstemleke (various Muslim and Non-Muslim Satellite States) But as one may readily perceive, an established regime allies itself with what might be termed 'Elements of Stability' in the social order and further attempts to insulate the stable elements from 'Elements of Instability.' To quote the Ottoman master of Ethics, Kinalizade:

...the Sultan is likened unto the perfectly skilled physician and the Reaya are likened unto the body and it is necessary for the physician (to know) how numerous are the maladies of the body and what are their symptoms and their causes and even how many are their remedies. Likewise also it is necessary for the Sultan (to perceive) the state of health of the realm to ensure its remaining within the limits of equilibrium and to know how it happens that the ailing jnembers proceed from equilibrium to morbidity and from soundness to imbalance.... if disorder has taken place and morbidity has set in upon the body of the state, let (the Sultan) destroy and remove it.... ${ }^{80}$

Generally speaking, however, a newly forming state must initially ally itself with 'Elements of Instability' in order to undermine the previously established order. A brief glance at our ten theoretical divisions of IslamicOttoman society will suffice to separate and to juxtapose 'Elements of Instability' to 'Elements of Stability':

\section{Elements Of Instability}

a) an inept dynasty

b) folk poets who generally were critical of established order ${ }^{81}$

c) Gazi warriors of mixed origins

d) family members of the Sultan holding government posts

\section{Elements Of Stability}

-a) a strong, creative dynasty

b) court or Divan poets, serving as apologists and propogandists

c) mamluks loyal to the person of the ruler

d) vezirs and governors subject to appointment and dismissal

80 Kinalızade Ali. Ahlāk-i Ala-i (Istanbul, 1248), Book III, p. 2.

81 Talât Halman has strongly supported this notion that the Halk (Popular) Poets generally opposed the central government while the Divan (Court) poets were generally little more than official propogandists for the regime. See Halman, "Poetry and Society: The Turkish Experience," in C. M. Kortepeter, ed., N. Y. U. Near Eastern Round Table II: Literature and Society in the Modern Near East (New York, 1971), 
e) the absence of or a poorly paid bureaucracy

f) dervishes with allegiance only to God and their sheykhs

g) turbulent, unjust local war lords

h) non-Muslims when persecuted or not particularly favored

i) radicalized craft guilds

j) merchants bankrupted by war or exploitation

k) peasantry, overtaxed and exploited

1) tribal units where the central government is weak e) a literate bureaucracy when properly paid and pensioned

f) the 'Ulema establishment if richly endowed with Evkaf

g) timar holders, regulated by the state

h) non-Muslims when specially favored; often leading to conversion

i) craft guilds favored or sharply controlled by the state

j) merchants favored by the dynasty

k) a prosperous peasantry

1) tribes carefully controlled or serving under military discipline

Of these twelve positive and negative elements of Islamic society, we are generally informed that the Osmanli initially drew upon the following elements for their support:

1. a strong, creative family, which suffered a minimum of altercation over succession to the leadership

2. a small core of personal servitors and mamluks

3. gazi condottieri and their followers

4. the $A h i$ craft guilds which were under futuwwa influence ${ }^{82}$ :

5. certain unspecified tribes

6. specially favored non-Muslims, many of whom became converts to Islam

7. certain of the dervish orders.

If we look at these disparate elements objectively, we realize that the principal 'Element of Stability' is the Ottoman family itself. But clearly, in the turbulent times of the late thirteenth century, a strong family was not a large enough social unit to attract the attention or the patronage, for example,

82 For a general treatment of the subject, see Franz Taeschner, art. "Akhi", in E. I. 2 I, pp. 321-323. 
of the figurehead Rum Seljuk Sultans even for such an appointment as that of a march lord (uc beyi), a position, Orhan was in possession of when Rum was visited by Ibn Battuta. Nor could a mere family command the allegiance of the turbulent condottieri and their gazis unless that family were quite wealthy. Following this line of reasoning, one must conclude that the Osmanli were members of or closely allied with a major social element of thirteenth century Asia Minor. That element, in spite of a number claims to the contrary, was probably a Turkish tribe. The sparse evidence at hand points in that direction. It is inconceivable to imagine that the powerful leaders of the gazis at the time of the formation of the $\mathrm{Ottoman}$ state would submit to the control of the Osmanli unless most to the constituent members of the gazi units were of tribal origin and also felt a special attachment to the Osmanli as the leading family of their tribe or tribal confederation. Moreover, it seems apparent that the original Osmanli were quite chummy with the $A h i(A k h i)$ craft guilds, the dervish orders and later on, the followers of Sheykh Safa of Erdebil. These tendencies lead us to three further conjectures: that the Osmanli probably came, not with the first wave of Turks in the eleventh century, but with the second wave in the thirteenth; that the Osmanli may have come to Asia Minor from Azerbaijan; and that, given the Shi'ite bias of the Ilkhans, the Osmanli were in a better position to receive support for their state-building from the Ilkhans than older and better-entrenched 'Elements of Stability' in the Rum Seljuk realm. With both tribal (their own) and official Ilkhan support, the Osmanli would then be in a strong position to control the condottieri of the gazis and to expand at the expense of strong neighbors such as Byzantium, the Bey of Kastamonu, the Germiyan Oğulları and others.

The early Ottoman chroniclers provide contrasting versions of early events in Ottoman history. Yazıcığlu Ali, following Ibn Bibi, associates the Ottomans with the Kayi tribe on whom supposedly devolved the heritage of Oghuz leadership. ${ }^{83}$ Aşikpaşazade gave importance to the right of conquest. He felt that the God-appointed conqueror should receive the unquestioned obedience of the people. Finally, Neşri, writing in the late fifteenth and early sixteenth centuries, indicated that the sovereignty of the Seljuks passed to the Osmanli because Alaeddin Kaykobad bin Feramuz, the Rum Seljuk ruler, had no offspring and hence favored Osman as his successor. ${ }^{84}$

83 For some rather relevant remarks about the Kayı, appart from Köprülü's monumental article mentioned in F. N. 70, see his article oa the Ortukids, "Artuk Oğulları", in I. A. I (1950), pp. $617-625$.

84 For a convenient summary of these chroniclers, see Irène Beldiceanu-Steinherr, Rec- 
Whether or not one accepts the Kayı provenience of the Osmanli, and much energy has been expended pro and con on the subject, ${ }^{85}$ the Yazıcığlu version has the advantage of age and also fits best the results of the preceding political analysis. If we accept the Osmanli as leaders of a tribal confederation of the type known to us in Central Asia, then all of the "Elements of Instability" with which the Ottomans worked initially to form a state are exactly those elements out of which new states were so frequently formed on the periphery of the steppe. Only after the Osmanl withstood tremendous pressures for dissolution-Gazi revolts, Dervish-led disorders, family squabbles, external threats- only then could the Osmanlı generate enough momentum to acquire wealth through territorial expansion, an increase in population, and the collection of booty and taxes. Only then could the Osmanl begin to attract and to pay the traditionally stable units of the Islamic polity: the bureaucracy, the 'Ulema, a Mamluk guard, and a 'service gentry.' Indeed, the transformation which took place in the $\mathrm{O}$ ttoman state between the mid-fourteenth and the mid-fifteenth centuries entailed chiefly the transferal of power from 'Elements of Instability' to these very 'Elements of Stability.' The grandchildren of the 'hungry and daring nomad' now sat in the seat of power.

But we have not yet answered one final enticing question: How did the Osmanl succeed in converting what started out as just one more ephemeral state into an empire lasting seven centuries? In the system of satellite states set up by the Mongols of Russia, the Golden Horde, we have an excellent model of what may have been attempted in Asia Minor by the Ilkhans much earlier. We know that Prince Ivan I of Muscovy (1325-1341) was recognized by the Khan of the Golden Horde as Grand Prince of all the Rus and given the task of collecting the Mongol taxes from the various Russian principalities, with the aid when necessary, of Mongol troops. It seems to be more than a coincidence that after the Mongol defeat of the Rum Seljuks at Kösedağ in

herches sulr es actes des règnes des sultans Osman, Orkhan et Murad I (Societas Academica Dacoromana, Acta Historica VII (Monachii, 1967), especially, pp. 67-68 and 72-73. One should also not overlook the important encyclopedia articles of M. Tayyib Gökbilgin, "Osman I', and "Orhan", in I. A. IX, (1962), pp. 431-443 and 399-408, respectively.

85 In particular, Paul Wittek's imjortant study, The Rise of the Ottoman Empire (London, 1938) emphasized the role of the Gazis or March Warriors while Köprüü set forth the theory of Kayi tribal provenience of the Ottomans in 1935 and then lent new facts to his case in the article cited in footnote 70 . 
1243, the Rum Seljuk Sultans collected the taxes from their dominion and satellites for the Mongols and with the aid of their detachments. Could it be that, as the respect for and the prestige of the Seljuk Sultans waned in the late thirteenth century, the Mongols appointed as uc beyleri those leaders of Turkish clans who would cooperate with the Ilkhans to the extent of having tacit or active Mongol support for the accretions of territory in the marches in exchange for the payment of a tax or pencik? Irène Beldiceanu-Steinherr appears to share this suspicion and has discovered the important observation of Shihab ed-Din al'Umari who lived in the early part of the fourteenth century: "Alors chacun de ces Tures s'attacha à capter la bienveillance des souveins mongols, afin de s'assurer la possession des états qu'ils avaient usurpés...." ${ }^{966}$

The quest for the 'Origins and Nature of Turkish Power' is at an end. It has taken us from the borders of China to the shores of the Bosphorus, a most fitting and exciting journey to take on the 900th anniversary of the victory of Manzikert. To this writer, it is a good omen that once again in this very year diplomatic relations have once again opened between these two ancient neighbors, the Chinese and the Turks.

\section{POSTSCRIPT}

I had abruptly ended my own speculations on the origins of the Osmanli, not because all had been said or reviewed, but because of the exigencies of time and space. Since writing the foregoing remarks, I have had the opportunity to read the brilliant contributions to the subject by Professors Halil Inalcik and Osman Turan in the Cambridge History of Islam I (Cambridge, 1970). In particular, one must give careful attention to what Turan has said about the distinction between the large iqta' given to leading emirs by the Great Seljuks and the modest tracts of timar placed at the disposal of warriors in Anatolia by the Rum Seljuks. ${ }^{87}$ Likewise we are indebted to Inalcik's ca-

86 Beldiceanu-Steinherr, pp. 69-70 citing F. Taeschner, Al-'Umari's Bericht über Anatolien in seinem Werk Masālik al-absär fi manālik al'amsār (Leipzig, 1929), p. 50. Köprülü in his "Osmanh Imparatorluğu'nun Etnik Menșei Mes'eleleri", Belleten VII (1943), pp. 289-291 and the accompanying footnotes, have some interesting remarks about chroniclers who, in order to discredit the Ottomans, spoke of their being Mongols.

87 O. Turan, "Anatolia in the Period of the Seljuks and the Beyliks", The Cambridge History of Islam I (Cambridge, 1970), pp. 254-255. See also, Ö. L. Barkan, "Osmanl Devrinin Eskicülü Mülkleri veya Mülk Timarlan Hakkında Notlar”, in Zeki Velidi Togan'a Armağan (Is- 
reful reconstruction of the atmosphere of the marches on the eve of the fourteenth century. In particular, his close reading of Pachymeres indicates that the gazi leadership moved from the Emir of Kastomonu to 'Osman. ${ }^{88}$ This fact lends further support to the thesis of Professor Wittek.

All of these conditions, including what has been said previously about the necessity of gaining an understanding of the purely Turkish background of the problem, seem to point to the following scenario for the early years of the fourteenth century. While obviously oversimplifying for the sake of brevity, one can say that power was exercised on four levels:

a) on the steppe and in the mountains, by tribal or semi-tribal leaders; or outlaw bands;

b) in the towns, by merchants and leaders of craft guilds, probably organized as $A h i$, wherever Mongol-Seljuk imperial garrisons were absent;

c) on the borders of Christian states, by Gazi leaders;

d) in the larger towns of the central Anatolian plateau, by Mongol-Seljuk imperial structures;

There might also have been some fifth level of power, namely, the leading members of minority groups.

It is clear that a community of interest, within limits, existed among the Ahi-controlled towns, the tribally-controlled remoter areas, and the gazi warriors. The 'glue' which held these divergent elements together was doubtless the dervishes..$^{89}$ But if we accept this conclusion, we must assume that there was either some towering spiritual figure such Sheykh Ede Bali who, in a sence, 'legitimized' the Osmanli as the divinely-guided leaders of the gazis or else the Osmanli were already a prominent family. In either case, the weight of evidence and logic would still seem to indicate some kind of tribal base, even for the mass of the gazis. In fact, in view of the long Turkish tradition of concentrating leadership skills in a few families-and the Osmanli clearly demonstrated high skills in diplomacy, military leadership and economic acu-

$88 \mathrm{H}$. Inalcik, "The Emergence of the Ottomans", Cambridge History of Islam I, p. 267. Köprülü, summarizing in Ülkï ]VII/4,2 (1936), p. 406 [the main findings of his book, les origines de l'empire ottoman (Pqris, 1935), presents a slightly different and yet rather attractive version of those early events around Kastononu and Paphlagonia.

89 The dervish orders are still known to perform similar services to this day. A description of the peace-making role of the devrishes and holy men in the Atlas Mountains appears in the book entitled, Lords of the Atlas, by Gavin Maxwell (New York, 1966). 
men- once again this writer has a preference for the theory of tribal provenience.

Finally, what about the residual strength of the imperial power? Perhaps this writer walks on thin ice in suggesting that the Osmanli had some special arrangement with the Mongol-Seljuk military or political structures. Most certainly the realities of a rugged terrani have goegraphic advantages to rebellious march warriors, but rough terrain had never checked the Mongols in the recent past. It is in this area of imperial diplomacy and economics that our scenario of early Ottoman history is still quite incomplete. In this respect, the articles of Professors Boyle and Petrushevsky in the Cambridge History of Iran, Volume V (Cambridge, 1968) are most enlightening. As he deals with political events at the beginning of the fourteenth century, Boyle leaves the distinct impression that the religious picture at the Ilkhan court was changing rapidly but that the imperial political and military might was still formidable. ${ }^{90}$ Petrushevsky, when discussing the reforms of Ghazan Khan and his immediate successors, clearly indicates, however, that the Ilkhans were undermining their political position, particularly in Iran, by economic policies which called for the unlimited exploitation of the Reay $\bar{a}$, cultivator and townsman alike, to the exclusive advantage of a leadership which based its power on nomads. ${ }^{91}$

Finally, if we accept the fact that the ties of the Ottomans with the imperial structures of their day were at best loose and ill-defined -and the Ottomans from an early date sought to protect the cultivator- we may conclude by suggesting ways the Osmanli drew upon their Turkic past to form their own empire. The Osmanli gradually changed their dependence upon gazis, dervish sheykhs, and the $a h i$ organization ('elements of instability') by creating initially units of timar-based warriors and later, by forming 'guard regiments' whether they were patterned after Turkish alp erenleri, Mongol bogatir (bahadir) or Islamic mamluk models or a combination of these traditions. The creation of units of timar holders depended on the rapid advance of the gazavāt (wars against the Infidel). The funding of mamluk structures, later termed Janissaries, depended upon the availability to the Osmanli of the pencik paid in gold or silver. Once the Ottomans were able successfully to cut their imperial ties and fiscal obligations, it would be at that time that we must expect 
the appearance of 'guards regiments' among the Osmanli. It would be solely the scarcity of gold and silver, not the concept of an elite guard which would prevent the establishment of a paid slave corps. The combining of the devşirme concept with the creation of a mamluk elite guard would appear to be a natural development of the Turkish tolerance towards non-Turkish subjects, a tolerance as old as the Turkish people. But here we are beginning toleave behind the events of the fourteenth century and are already anticipating events which become very significant indeed in the post-Timur (Tamerlane) world of the Ottomans.

To recapitulate, Turkish power developed out of the harsh requirements of economic life on the steppelands of inner Asia. Survival on the steppe was assured through a strict authoritarian family structure. Gradually certain key families possessing wealth, daring, brains and power gained recognition and ascendency over other families. The position of the head of the family and of the leading family of a tribe was enhanced and legitimized by shamanist practices and the elitist oral literary traditions. The steppe environment trained leaders to take full advantage of such disparate economic units as irrigated agriculture, forest economy, nomadism, and long range transport and commerce. This environment was also conducive to tolerance of various peoples and religions owing to the active presence of various faiths and ethnic groups. In an era when horsemanship (furusiye) and archery were the dominant skills in warfare, few were the states which could match these skills which the nomads exercised every day to assure their livelihood.

The hierarchical and patriarchal political structure of the Turks gained stronger religious sanctions and legitimacy than shamanism could provide with the conversion of the Turks to Islam; and conversely, all facets of Islam were subjected to a political reorganization by the Turks which assured to Islam its survival and advance into modern times. The strong social organization of the Turks and their highly developed sense of loyalty to their kinsmen and leaders contrasted sharply with the social unrest and political disunity of the Byzantine and Arab lands of the eleventh century. Two hundred years later, at the close of the thirteenth century, when another wave of Turks was settling in the Near East, the social and political organization of the Turks once again proved markedly superior to other competing political systems. Herein lies the secret of Manzikert and 900 years of Turkish prominence in the eastern Mediterranean. 